\title{
A qualitative case study research investigation of youth outcomes during an Appalachian water-quality citizen science program
}

Jessica Kaplan

West Virginia University, jek0035@mix.wvu.edu

Follow this and additional works at: https://researchrepository.wvu.edu/etd

Part of the Outdoor Education Commons, and the Science and Mathematics Education Commons

\section{Recommended Citation}

Kaplan, Jessica, "A qualitative case study research investigation of youth outcomes during an Appalachian water-quality citizen science program" (2020). Graduate Theses, Dissertations, and Problem Reports. 7812.

https://researchrepository.wvu.edu/etd/7812

This Thesis is protected by copyright and/or related rights. It has been brought to you by the The Research Repository @ WVU with permission from the rights-holder(s). You are free to use this Thesis in any way that is permitted by the copyright and related rights legislation that applies to your use. For other uses you must obtain permission from the rights-holder(s) directly, unless additional rights are indicated by a Creative Commons license in the record and/ or on the work itself. This Thesis has been accepted for inclusion in WVU Graduate Theses, Dissertations, and Problem Reports collection by an authorized administrator of The Research Repository @ WVU. For more information, please contact researchrepository@mail.wvu.edu. 
A qualitative case study research investigation of youth outcomes during an Appalachian water-quality citizen science program

\author{
Jessica Kaplan \\ Thesis submitted to the \\ Davis College of Natural Resources and Design \\ at West Virginia University \\ in partial fulfillment of the requirements for the degree of \\ Master of Science \\ in \\ Recreation, Parks, and Tourism Resources
}

David Smaldone, Ph.D., Committee Chairperson

Steven Selin, Ph.D.

Chad Pierskalla, Ph.D.

Division of Forestry and Natural Resources

Recreation, Parks, and Tourism Resources Program

Morgantown, WV

December, 2020

Keywords: citizen science, environmental education, knowledge, awareness, motivation, self-efficacy, behavior, water-quality, informal science education, youth

Copyright 2020 Jessica Kaplan 


\begin{abstract}
A qualitative case study research investigation of youth outcomes during an Appalachian waterquality citizen science program

Jessica Kaplan

Citizen science has grown in the past decades to not only include everyday people in research, but also varying levels of engagement with diverse opportunities for participant learning and growth. However, few studies reflect the actual learning outcomes of educational citizen science specifically in youth. This single case study research study focuses on assessing learning and other outcomes of an environmental education, collaborative citizen science program with youth in Morgantown, West Virginia. In this study, a water quality monitoring citizen science program focused on Deckers Creek in Morgantown, WV was adapted for a high school afterschool club. Potential outcomes of the program were identified using environmental education theory and current citizen science frameworks. Semi-structured interviews were conducted with eight participants approximately one year and a half into the project to gauge participant outcomes. Open and axial coding was used to identify actual participant outcomes, then compared with those identified in the literature. Results of the interviews demonstrated that participants described a change in motivations to participate in the club, change in awareness of environmental issues of Deckers Creek, gain in knowledge related to science content and science process, an increase in self-efficacy related to science, and a change in actual and intended behavioral changes. Students were able to thoroughly describe water quality and watershed issues in Deckers Creek. By understanding participant outcomes, we can learn how a citizen science experience such as this one can contribute to learning in a non-formal education experience and potentially meet the goals of science education for youth.
\end{abstract}


Table of Contents

Chapter 1: Introduction 1

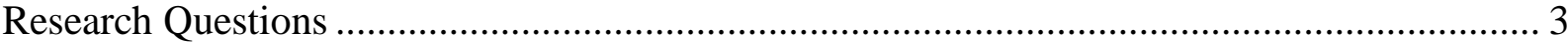

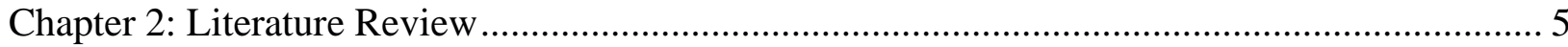

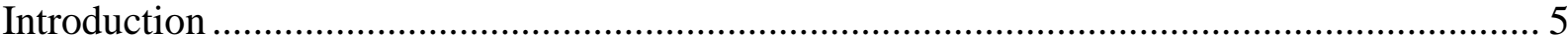

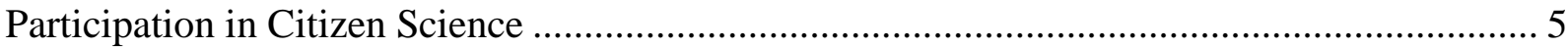

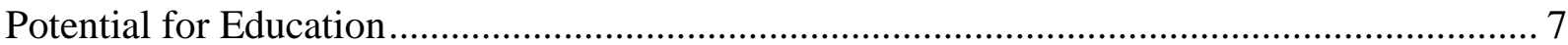

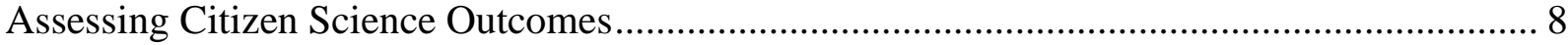

Citizen Science for Youth Education .............................................................................. 9

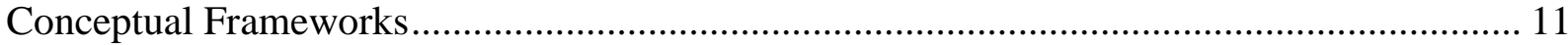

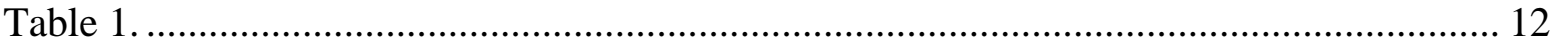

Potential Learning Outcomes from Frameworks ........................................................... 14

Content Knowledge and Environmental Awareness ..................................................... 14

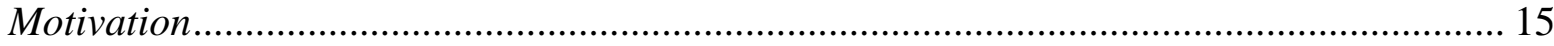

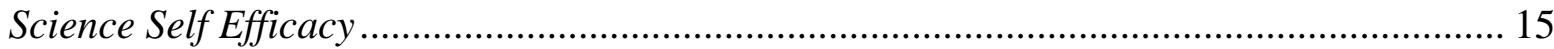

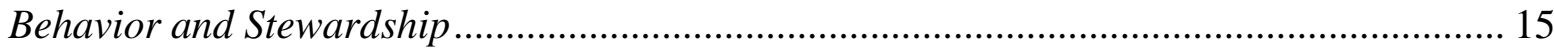

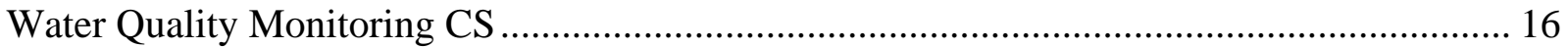

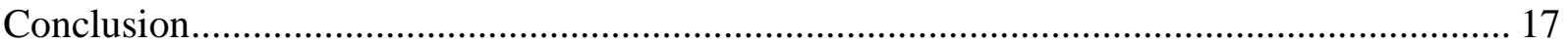

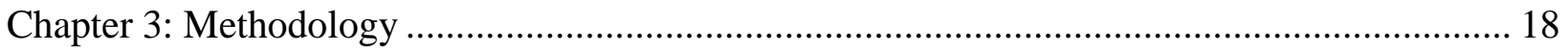

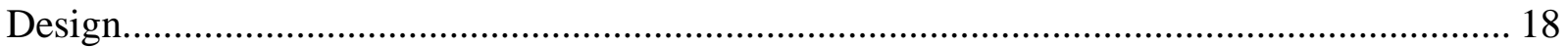

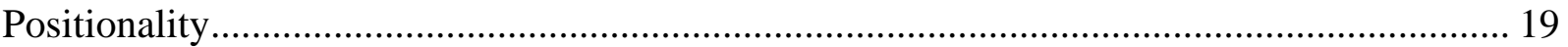

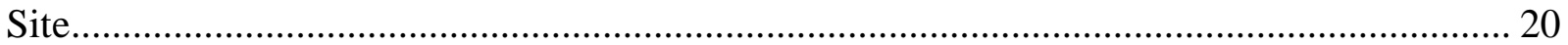

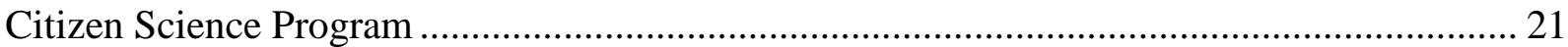

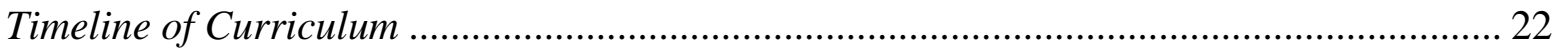

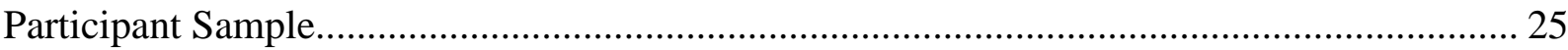

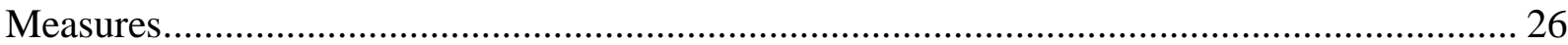

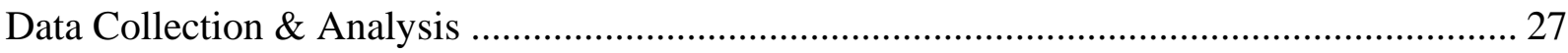

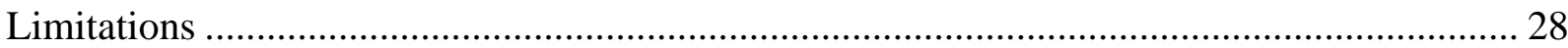

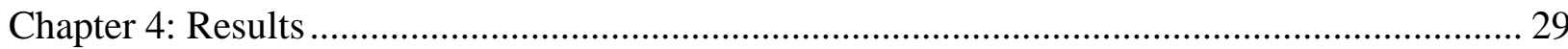

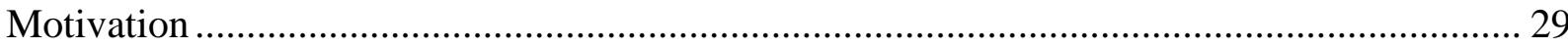

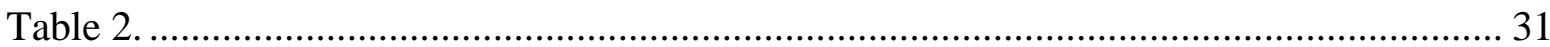

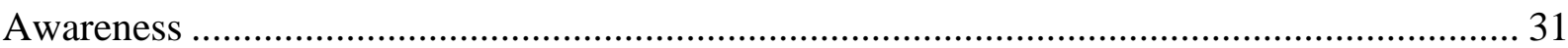

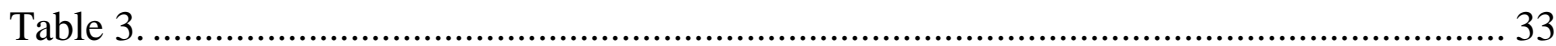




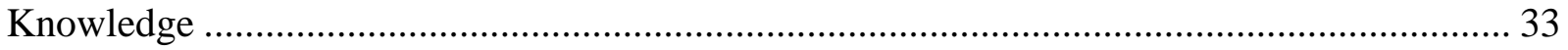

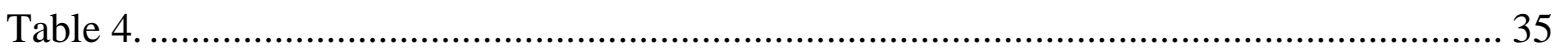

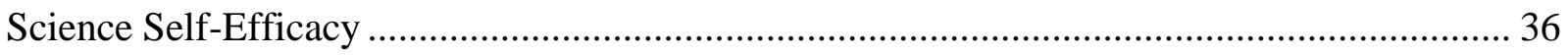

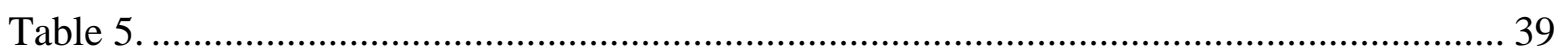

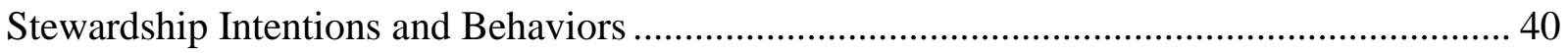

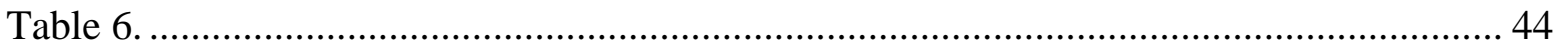

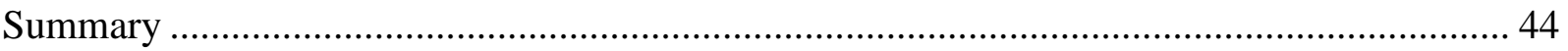

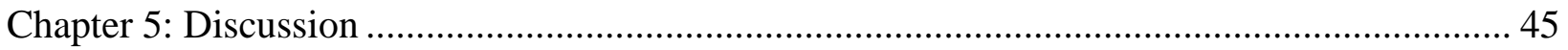

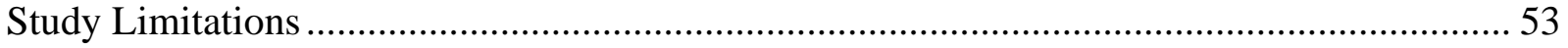

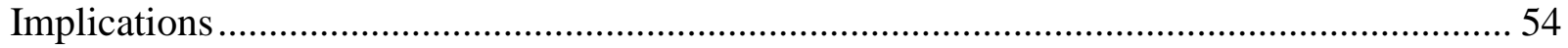

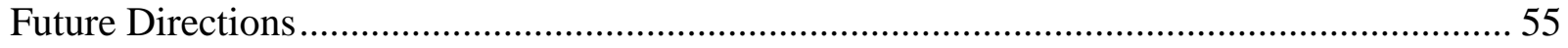

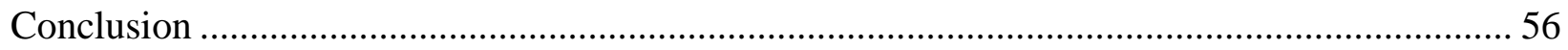

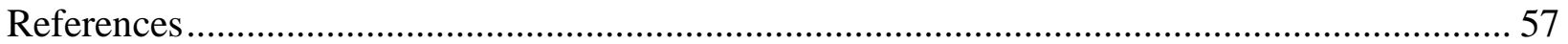

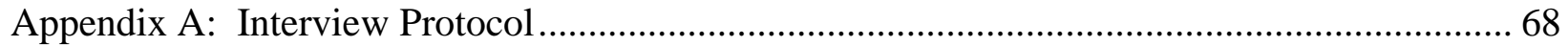

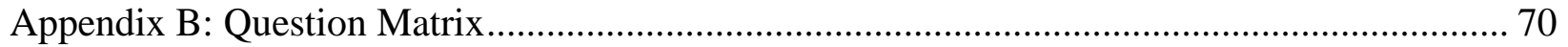

Appendix C: Curriculum \& Activities ................................................................................ 74

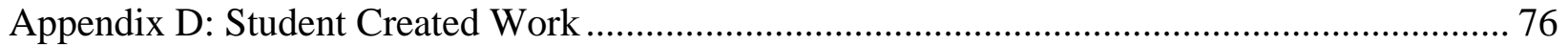




\section{Acknowledgements}

There are so many people who have supported me over the past two years, without whom, none of this would be possible.

First and foremost, I would like to express my sincere gratitude for my major advisor and teacher, Dr. Dave Smaldone. Thank you for always challenging me and for being a constant source of encouragement and motivation. I appreciate all of the effort and support you've given me during my time at WVU. Your mentorship was invaluable and your humor was much needed.

Second, I would like to thank the project partners who made this possible, including Christian Root, everyone from the Friends of Deckers Creek, Dr. Jim Anderson, Dr. Nancy Spillane, and Megan Kruger. Thank you for all of your work to make this project happen. To all of the wonderful students of WATER club, your hard work helped to restore our environment and educate our community. Thank you for allowing me to share your experiences. I would also like to acknowledge the United States Environmental Protection Program for funding this program.

I would also like to thank my committee members, Dr. Steven Selin and Dr. Chad Pierskalla, who have both taught me so much during my time at WVU and have been instrumental in this process. To the rest of the Division of Natural Resources and Educational Psychology faculty, thank you for helping me succeed.

Thank you to all of my friends in Morgantown, who were a constant support. A special thank you to Lauren Janowitz, Dr. Alice Morgan, and Maya Mier-Thomas, who have all been sources of strength and inspiration throughout this journey. Finally, I would like to thank my family for always believing in me. 


\section{Chapter 1: Introduction}

In the past 20 years there has been a considerable growth in social science research focused on citizen science, which is often referred to as public participation in scientific research, citizen and community science, or volunteer monitoring (Bonney et al. 2009). As a research tool, citizen science provides efficient and cost-effective data collection (McKinley et al., 2016) which can be of comparable accuracy to trained scientists (van der Velde et al. 2016; Fuccillo et al. 2015). Citizen science also has benefits for those who participate (Dickinson et al., 2012). Recent literature has shifted to focus on the outcomes of participating in citizen science to further understand it's benefits for learning.

A growing number of citizen science projects have started incorporating educational goals and objectives (Bonney et al. 2009; Phillips et al, 2016) to increase the public understanding of science (Bonney et al. 2016). Potential learning outcomes for participants have been identified using informal science education frameworks (Phillips et al. 2018; Friedman et al. 2008; NRC 2012). A recent review by Phillips et al. 2018 identified six broad categories of potential learning outcomes within current research: interest, self-efficacy, motivation, content, skills of science inquiry, and behavior or stewardship. Their work recognizes that while these constructs have been identified as potential outcomes, the overall available research on these outcomes combined is sparse with the primary focus on adult participation and little work on youth outcomes (Phillips et al. 2018), Further, the majority of the available literature focuses on knowledge gained within the programs, so the other participant outcomes remain severely uninvestigated (Peter et al., 2019; Stepenuck \& Green, 2015). 
Available literature reviews on citizen science programs reveal few recent studies that measured participant outcomes. A review of biodiversity citizen science programs between 2008 and 2017 revealed only fourteen articles that measure participant learning outcomes out of a sample of 608 articles (Peter et al., 2019). Water quality monitoring citizen science programs are considered to be one of the largest citizen science activities (Conrad \& Hilchey, 2011; GrudensSchuck \& Sirajuddin, 2019) with an estimated 1,720 groups in the U.S. engaging in water quality monitoring as of 2014 (National Water Quality Monitoring Council, n.d.). A review of the existing literature on participatory water quality monitoring through 2012 revealed out of a sample of 436 peer-reviewed journal articles, only 35 had reported outcomes for participants (Stepenuck \& Green, 2015), with the highest reported outcome being knowledge gain. The need for further research into learning within citizen science in general is apparent. However, there is also a gap in the literature for youth participants.

This lack of research on youth learning in citizen science is surprising considering the growing number of curricula based or educational citizen science projects (Dickinson et al. 2012; Trautmann et al. 2012). Citizen science often provides an opportunity for youth to engage in inquiry and the process of science, making it a natural addition to formal and informal science education. Understanding how learning occurs while participating in citizen science could be especially helpful to formal educators who often look to environmental education for an engaging, hands on experience (Kountoupes \& Oberhauser, 2008). Environmental education aims to "produce citizenry that is knowledgeable concerning the biophysical environment and its associated problems, aware of how to help solve these problems, and motivated to work toward their solution" (Stapp, 1969). Integrating these two fields could obtain desired learning outcomes 
for youth in science education while contributing to the quality of their local environment (Wals et al. 2014).

The purpose of this study was to understand the actual learning outcomes for youth during a collaborative citizen science program (Bonney et al., 2009) that incorporates environmental education activities (Hungerford \& Volk, 1990). The majority of citizen science research has focused on quantitative measures using surveys, providing data related to what outcomes the programs have achieved (Peter et al., 2019). However, these quantitative measures have only provided limited insights into how learning occurs within these programs. This study used qualitative research methods in order to provide such context and understanding of participants' experiences and their learning. A citizen science framework developed by Phillips et al. 2018 and an environmental education framework from Hungerford and Volk (1990) was used to identify appropriate constructs for collaborative citizen science programs. Knowledge, awareness, motivation, self-efficacy and stewardship behavior were analyzed in the context of a collaborative citizen science program that provides opportunities for environmental education.

\section{Research Questions}

1. What outcomes do students describe after participating in a collaborative water quality citizen science program?

2. What themes arise within these outcomes?

Construct specific research questions:

1. What are the motivations for youth who participated in WATER club?

2. How does participation in WATER club impact youth's awareness of the issues of Deckers Creek? 
3. How does participation in WATER club impact knowledge of conducting science, water quality, and citizen science?

4. How does participation in WATER club impact student's science self-efficacy?

5. How does participation in a collaborative, citizen science program impact youth's beliefs and/or actions about stewardship? 


\section{Chapter 2: Literature Review}

\section{Introduction}

Citizen science is the intentional involvement of non-professionals or members of the public in scientific research. It is sometimes referred to as community science, public participation in scientific research, volunteer monitoring or more recently community and citizen science (Miller-Rushing et al., 2012; Dickinson et al. 2012; Phillips et al. 2018; Bonney et al., 2009a; Wiggins \& Crowston, 2011; Ballard et al., 2017) with slight subtleties between terms. The practice of using the public or volunteers to collect data for scientific research has been used for hundreds of years to answer large scale research questions (Miller-Rushing et al., 2012). Recently this definition has expanded to include other tasks necessary in the research process that involve the public (Bonney et al. 2009a). Much research has been done on the effectiveness of citizen science as a research tool focused on the science, (Dickinson et al., 2012), but a developing field of educational research is growing around the potential outcomes for citizen scientists or those who participate in citizen science. Because citizen scientists are directly involved in one or more steps of the scientific method, this can lead to "hands-on" experiences or inquiry-based learning (Bombaugh, 2000) as well as an increased understanding of science and the process of conducting scientific research (Bonney et al. 2009a). Because of this, citizen science has been used as a tool for education for the general public and youth.

\section{Participation in Citizen Science}

In order to understand how citizen science can impact a participant, it is important to understand what participation in citizen science actually looks like today. There are a wide variety of projects available, with some living entirely online, such as Galaxy Zoo, where participants log onto Zooniverse.org and help scientists classify photos of asteroids by their 
shape. Other projects such as eBird, hosted by Cornell University, have participants identify bird species they see outside their homes or during their travel and allow them to share their sightings on a mobile app. Participants in both projects are engaging in citizen science, however they differ in settings, effort, skills, knowledge and technology need to participate. With thousands of projects aimed at millions of participants (Bonney et al., 2014), there is a plethora of opportunities to engage with citizen science.

Participant engagement in a citizen science project generally increases as the task of citizen scientist moves from entry level data collection to potential data analysis, communicating to others, or conducting more steps in the scientific method. These levels from least participation to most have been labeled contributory, collaborative, and co-created (Bonney et al., 2009a). According to Bonney et al. (2009a), contributory projects are primarily designed to involve members of the public in data collection. Collaborative citizen science projects are generally designed to allow the public to collect data but may also help to refine the project design, analyze data or share the results (Bonney et al, 2009a). Finally, co-created projects are designed by both the public and scientists together and both parties are active in all the research processes (Bonney et al., 2009a). These categories were later expanded by Shirk et al. (2012) to include contractual and collegial citizen science programs.

Participation and engagement is a widely cited classification or typology of citizen science, but others do exist such as Wiggins and Crowston's categorization of Action, Conservation, Investigation, Virtual, and Education (2011); Bonney et al.'s classification of Data Collection, Data Processing, Curriculum-Based and Community Science (2016) or more recently the Stasser et al. classification of Sensing, Computing, Analyzing, Self-reporting and Making 
which focuses on the qualitative aspects of the program and does not assume a hierarchy of engagement (2019).

Phillips et al. (2018) suggests that the previous classifications of engagement in citizen science through project type such as contributory, collaborative and co-created did not accurately depict what engagement actually looks like within citizen science. Instead, they propose a new framework specifically for engagement, the Dimensions of Engagement Framework that incorporates how participants can be engaged through behavioral activities, affective/feelings, learning/cognition and social/project connections (Phillips et al. 2019). Understanding how people can potentially engage with citizen science ultimately helps to uncover the outcomes of participating in these various projects.

\section{Potential for Education}

Early work on the outcomes of citizen science focused on science literacy and science education. In the late 20 th century and early 21 st century there was a push for a general public understanding of science (Liu, 2009), that can be seen through reforms of the National Science Education Standards (National Research Council; 1996). Research during this time from the National Science Board showed that the general public understanding of basic scientific concepts and inquiry was insufficient for informed decision making (National Science Board, 2002). Informal science education was seen as a possibility to engage the public and youth with science outside of the classroom. Early studies of the educational potential of citizen science tried to tackle the question if informal education like citizen science can be used to address science literacy broadly and specifically on various constructs like inquiry, knowledge, and attitude towards science (Trumbull et al., 2000; Brossard et al., 2005; Evans et al., 2005). This sparked a field of research interested in assessing learning outcomes through citizen science. Now there is 
more available literature on the potential for citizen science to be used in the context of informal science education (National Academy of Science, 2018).

\section{Assessing Citizen Science Outcomes}

Initial assessments of citizen science relied on evaluations that provided details about the participant demographics, but relied on participant self-reports of knowledge and attitude changes (Brossard et al., 2005). There was not a unified approach to assessing outcomes throughout the literature and some evaluation of participant outcomes used a variety of theories and measures to tackle what outcomes could participants show when engaging in citizen science (Phillips et al., 2018). Through these past two decades of research, we now understand that citizen science has the potential to evoke participant outcomes such as developing science inquiry skills (Trumbull et al., 2000; Becker et al., 2013; Meyer et al., 2014); increasing participant's knowledge of scientific content related to the program (Brossard et al., 2005); behavior and stewardship, self-efficacy, motivation to achieve a science or environmental activity and interest in science. The majority of studies done on learning outcomes of citizen science have focused on learning in adults (Phillips et al. 2018). Further a review of biodiversity citizen science projects revealed that the most commonly studied outcome was content knowledge, generally suspected to be because of the educational objectives in the citizen science programs (Peter et al., 2019).

Poor project and assessment planning can lead to project implementation that does not reach the intended goal (Druschke \& Seltzer, 2012) and therefore lose the opportunity to achieve the intended learning outcomes. And just because a project might offer resources that aid in learning, does not mean that learning is properly facilitated. For example, Thompson, Bonney, and Bearman (2007) showed that the majority of "active users" of eBird, a popular citizen 
science online project, did not properly use the extensive online data-analysis tools and may have been drawing inaccurate conclusions about their data because of a lack of knowledge on how to use these tools for their particular research question. Best practices in CS project design now entail linking project goals and objectives to specific learning outcomes, especially in formal learning environments, such as curriculum-based projects.

\section{Citizen Science for Youth Education}

While there is a great deal of literature available on potential outcomes for adults, there is a lack of unified research on the specific outcomes for youth learning through citizen science. There has been a recent shift in using citizen science in classrooms by teachers to address learning outcomes identified in the Framework for K-12 Science Education and the Next Generation Science Standards (National Research Council, 2012; Bird, 2019), however, there is still a gap in studies that effectively assess the learning outcomes of youth participation in citizen science (Bird, 2019; Ballard et al., 2017; Phillips, 2017; Crall et al., 2012; Hiller \& Kitsantas, 2014; Kountoupes \& Oberhauser, 2008; Trumbull et al., 2000).

Kountoupes and Oberhauser (2008) used a mixed methods approach to identify youth outcomes during an informal citizen science project, the Monarch Larva Monitoring Project. The adult leaders during the project were surveyed and interviewed on their perceptions of their youth group's outcomes, which included "understanding real scientific research", "feeling like a scientist", "doing something important", learning about the content of the project, social gains, potential career focus, and leadership skills (Kountoupes \& Oberhauser, 2008, p. 15). While this study showed the potential for youth outcomes through citizen science, further research that involved youth directly reveals additional outcomes. 
Quantitative approaches to understanding youth outcomes have faced challenges in survey design from a lack of unified measurement tools. Hiller and Kitsantas’ quasiexperimental study of the effect of a citizen science program on STEM career motivations and science performance showed that self-efficacy, interest, academic achievement and expectations all influenced career planning (2014). Crall et al. also surveyed youth participants in a horseshoe monitoring citizen science program and found impacts to science literacy and content knowledge related to the resource, as well as self-reported pro-environmental behaviors, through pre/post surveys (2012). However, these increases were marginal (Crall et al. 2012).

Pitt and Schultz used a qualitative, mixed methods, multiple case study research approach to analyze three different Forest Service sponsored citizen science projects to see if these projects are currently meeting their objectives for students' outcomes (2018). Their student interviews revealed that students in the Alaska Natural Science Course, which involves visits from the Forest Service to the classroom and one field trip for a duration of one semester, showed an increase in knowledge related to the resource studied and an increase in stewardship and appreciation of the resource (Pitt \& Schultz, 2018). Interview analysis of their second case study, Montana Youth Forest Monitoring Program which is a seven-week internship, showed that students had an increase in career interest in science from the program and knowledge of data collection methods (Pitt \& Schultz, 2018). Finally, their last case, Delta Apprenticeship in Science and Engineering which is a six-week program for two students, showed youth outcomes such as an increase in knowledge of science and engineering topics and an increased career interest in science (Pitt \& Schulz, 2018). These case studies show the potential significance of longitudinal research on youth outcomes in citizen science using qualitative methods. 
Some citizen science projects have adopted specific outcomes related to science education, which are then labeled curriculum-based projects. A curriculum-based project focuses on having learning outcomes and lesson plans to achieve that specific goal (Bonney et al., 2016). A variety of curriculum-based citizen science projects are now available that draw upon environmental educational activities (Wals et al., 2014; Bonney et al., 2016; Trautmann, 2013). For example, the University of Minnesota's environmental education program, Driven to Discover, provides curriculum for both classroom use and youth programs on pollinators, phenology, birds, dragonflies (Driven to Discover, n.d.) Curriculum guides from Cornell University, such as BirdSleuth, employ a similar hypothesis driven approach. Curriculum-based citizen science demonstrates the potential power of citizen science, environmental education, and science education to facilitate youth learning which is described by Wals et al. (2014). While the benefits of such a program are apparent for science education, there is a lack of a unified theoretical framework for this type of citizen science program. The theoretical frameworks for each could be compared to provide more appropriate potential outcomes for participants.

\section{Conceptual Frameworks}

Recent conceptual frameworks have emerged to understand learning outcomes from citizen science. One framework proposed by Phillips et al. (2018), which incorporates strands from both the National Science Foundation (Freidman, 2008) and the National Research Council Framework (2012) identifies six main learning outcomes in citizen science: interest, selfefficacy, motivation, content and the nature of science knowledge, skills of science inquiry, and behavior \& stewardship. While these learning outcomes are possible when engaging in citizen science, not all of them can or should be achieved by a single project (Phillips et al., 2018). When determining which learning outcomes are appropriate for what projects, it is important to 
understand the project's goals and objectives, which should define the specific intended outcomes (Jordan et al., 2012). Environmental education theory could be used to help identify appropriate learning outcomes for these projects and help move forward citizen science research.

One widely cited environmental education framework discusses how to move participants though a continuum of outcomes, from awareness and interest, to knowledge and skill development to finally stewardship behavior (Hungerford \& Volk, 1990) through entry, ownership and empowerment level. It appears that citizen science and environmental education offer complementary approaches to move participants towards stewardship, yet little research has addressed this. For example, entry level activities such as awareness can be linked with entry level participation in citizen science (contributory) and ownership and empowerment level activities like behavior can be linked to higher engagement projects, such as co-created citizen science programs (Hungerford \& Volk, 1990) as seen in Table 1 below.

\section{Table 1.}

\section{Comparison of Citizen Science and Environmental Education Outcomes}

\begin{tabular}{|c|c|c|c|}
\hline $\begin{array}{c}\text { CS Project } \\
\text { Type }\end{array}$ & $\begin{array}{c}\text { Engagement } \\
\text { \& Time } \\
\text { Commitment }\end{array}$ & $\begin{array}{c}\text { Hungerford \& } \\
\text { Volk's model of } \\
\text { Responsible } \\
\text { Environmental } \\
\text { Citizenship }\end{array}$ & $\begin{array}{c}\text { Potential Appropriate Outcomes to } \\
\text { Target (Bonney, et. al., 2009a; } \\
\text { Friedman, 2008; NRC, 2009; Phillips } \\
\text { et al. 2018) }\end{array}$ \\
\hline Contributory & Low level & $\begin{array}{c}\text { Entry level } \\
\text { variables }\end{array}$ & $\begin{array}{l}\text { 1) Interest; appreciation; engagement } \\
\text { 2) Awareness; Limited knowledge- } \\
\text { related to resource (water quality, etc.) }\end{array}$ \\
\hline
\end{tabular}




\begin{tabular}{|c|c|c|c|}
\hline Collaborative & $\begin{array}{l}\text { Moderate } \\
\text { level }\end{array}$ & $\begin{array}{c}\text { Ownership level } \\
\text { variables }\end{array}$ & $\begin{array}{l}\text { 1) Increased interest; appreciation; } \\
\text { engagement } \\
\text { 2) Awareness; Limited knowledge-- } \\
\text { related to resource, \& science process } \\
\text { 3) Identity (attitudes; confidence; } \\
\text { personal "investment", etc.) } \\
\text { 4) Skills_-related to procedural steps in } \\
\text { CS projects (data collecting, etc.) }\end{array}$ \\
\hline Co-Created & High level & $\begin{array}{l}\text { Empowerment } \\
\text { level variables }\end{array}$ & $\begin{array}{l}\text { 1) Increased interest; appreciation; } \\
\text { engagement } \\
\text { 2) Increased knowledge \& } \\
\text { understanding_related to resource, \& } \\
\text { science process (moving towards } \\
\text { scientific literacy) } \\
\text { 3) Increased Identity (attitudes; } \\
\text { confidence, etc.) } \\
\text { 4) Behavior \& Skills-intentions \& } \\
\text { behaviors related to project \& science } \\
\text { (participating in other CS; conservation, } \\
\text { etc.) }\end{array}$ \\
\hline
\end{tabular}

This alignment of the appropriate outcomes noted above from Phillips et al., (2018) to the Responsible Environmental Citizenship model (Hungerford \& Volk, 1990) allows for a distinction of outcomes between levels of engagement in citizen science projects. Commonly accepted objectives for environmental education include awareness, knowledge and understanding, attitudes, and skills. For this study, the contributory level of engagement was used based on the outcomes that fall within the ownership level of the Responsible Environmental Citizenship model, which most closely includes increased interest and awareness, limited knowledge, identity and skills (Hungerford \& Volk, 1990). These outcomes have also been identified from results of citizen science participation as previously outlined in the framework from Phillips et al. 2018 and were considered the anticipated or hypothesized 
outcomes of this study. The outcomes this case study research focused on were those that were appropriate for a collaborative citizen science program.

\section{Potential Learning Outcomes from Frameworks}

The following outcomes noted above will be discussed in detail below and have been identified from the previous citizen science frameworks and environmental education frameworks (Phillips et al., 2018). These are all potential outcomes that could occur within a citizen science program, but the degree to which they occur will differ depending on the actual objectives of the program (Jordan et al., 2012). As noted earlier, based on the wide diversity of CS projects and levels of participant engagement, all CS projects should not attempt to address all these outcomes.

\section{Content Knowledge and Environmental Awareness}

Phillips et al. 2018 separates knowledge into three main categories: 1) knowledge and understanding of science content, such as facts or concepts; 2) knowledge and understanding of the science processes or the methodologies used to conduct research; and 3) the knowledge of the Nature of Science or how science is used to generate knowledge. Awareness is closely related to knowledge and understanding and in some cases reported together (Phillips et al. 2018). All projects that require public participation usually contribute to awareness, knowledge and the understanding of the scientific concepts discussed in the project (Bonney et al. 2009b). For example, Jordan et al. (2011) saw an increase of awareness of the effects of invasive plants on the environment with awareness and knowledge used interchangeably. The Neighborhood Nestwatch program (2005) also reported awareness and knowledge gains, however, these terms were also used interchangeably. These studies failed to define awareness, so we will look to environmental education, where awareness is a key construct in the Responsible Environmental 
Citizenship Model, and is defined as a "sensitivity to the total environment and its allied problems and/or issues" (Hungerford and Volk, 1990, p. 258).

\section{Motivation}

Motivation for participation in citizen science can be defined as "goal-driven inclination to achieve a science or environmental behavior or activity" (Phillips et al. 2018; Peter et al., 2019). A review by Peter et al. in 2019 showed that out of 14 recent biodiversity citizen science studies that measured participant outcomes, none explicitly measured motivation for studying science and the environment, even though motivation was listed as a viable outcome for participants in the framework developed by Phillips et al. (2018). This represents a significant gap in the literature on motivations for science and the environment in biodiversity citizen science projects (Peter et al., 2019). Other studies on motivation have focused on similar constructs, including STEM career interest (Hiller \& Kitsantas, 2014).

\section{Science Self Efficacy}

Self-efficacy describes a person's beliefs about their ability to learn specific content and to perform a specific behavior (Bandura, 1997). According to Phillips et al. 2018 (p. 8), selfefficacy for citizen science "is the extent to which a learner has confidence in his or her ability to participate in a science or environmental activity." Interestingly, studies have noted that an increase in awareness of citizen scientist's own scientific knowledge and ability may actually lead to a drop in confidence in their own scientific knowledge and ability because of the realization of how much there is to learn (Price \& Lee, 2013; Bonney et al., 2016).

\section{Behavior and Stewardship}

Behavior change and stewardship in citizen science can be defined as "measurable actions resulting from engagement in citizen science, but external from the protocol activities 
and the specific project-based skills" (Phillips et al. 2018, p. 10). In their review of behavior and stewardship in citizen science, Phillips et al. identified five categories of behaviors: global stewardship, place-based behaviors, new participation, community or civic action, and transformative lifestyle changes (2018). Research to support these potential behaviors has been limited. Knowledge of how to perform the changed behavior has to be explicitly made to participants (Phillips et al. 2012; Tommey \& Domroese, 2013). Environmental education also utilizes the construct of stewardship behavior and change. The previously cited environmental citizenship model from Hungerford and Volk describes the linkage of environmental sensitivity, attitude, knowledge, skill and locus of control that contribute to citizenship behavior (1990). This describes the process that a participant needs to go through in order to perform stewardship or environmental citizenship behavior, such as becoming aware of the issue, learning more about the issue, and personally investing in the environment before they feel they are able to do something about it and intent to act in a pro-environmental way.

\section{Water Quality Monitoring CS}

Water quality monitoring citizen science represents one of the most prolific forms of public participation in research, with an estimated 1,720 current water quality monitoring groups (National Water Quality Monitoring Council, 2020). A review of volunteer water quality monitoring programs in 2015 revealed that outcomes for participants include: knowledge gain, change in attitudes or behaviors, attainment of social and personal benefits, attainment of voice in decision making, and an increase in amount and effectiveness of civic participation (Stepneuck \& Green, 2015). Not only does studying water quality outcomes for participants benefit the citizens, it also can have benefits for program designers and researchers using citizen science. A recent review of freshwater citizen science programs focused on the attributes of 
citizen scientists that lead to successful programs found that participants who were knowledgeable and had experience with data collection (or prior experience with citizen science), aware of environmental issues, and motivation, and socio-economic background all played an important role in the success of a water quality monitoring project (Capdevila et al. 2020).

\section{Conclusion}

Citizen science can lead to educational benefits for its participants, especially youth, however more research on the actual outcomes achieved through various project designs is needed to substantiate these findings. Important questions remain, such as what type of CS project leads to what type of learning outcomes, or what level of participant engagement leads to what type of learning outcome? Moreover, the use of citizen science in education has the potential to reach educational standards for formal and nonformal education. Additionally, qualitative case study research (Yin, 2015) could allow for a deeper understanding of how participation and learning is linked to outcomes in citizen science. This presents a gap in the available literature on educational outcomes for youth involved in water quality monitoring citizen science, which this study focused on. 


\section{Chapter 3: Methodology}

\section{Design}

Citizen science suffers from a lack of quality cross-programmatic research (Phillips et al., 2012; Phillips et al., 2018) due to site and program specific outcomes and also to the time and expertise needed to conduct social science research. The variety of ways participants engage in programs this further complicates the issue. This study used a qualitative retrospective case study research design to understand youth participant outcomes in the context of a citizen science program (Yin, 2015; Street \& Ward, 2012). The aim of qualitative research is to understand how individuals interact and make meaning in with their world (Merriam, 2002). This differs from using a quantitative approach because there can be multiple realities and lived experiences and so the goal is to understand that reality at a moment in time (Merriam, 2002). In a qualitative interview, it is the work of both the participant and the research to make sense of the participants experience and make meaning (Brinkman \& Kvale, 2015). This approach allows for greater depth and richness of answers to research questions and reveals the "how" and "why" of a participant's answers, which was a goal of this study to understand how these outcomes come to be through the participants own experiences.

Water quality monitoring programs often record similar scientific information, specific aspects of the program such as scientific activities, goals, objectives and target audiences are unique to each program and the local context (Bela et al., 2016). Because context matters, citizen science lends itself well to case study methodology, which will be used in this study to understand participant experiences and learning. Recent publications on citizen science and education have used a single case study research methodology (Aivelo \& Huovelin, 2020; Harris, 2017). Some have even chosen to focus on an individual within a program (Bird, 2019). 
The bounds for this case study research were the WATER (West Virginia Action Towards Environmental Restoration) Club, the contextual setting in which the high school students participated in both the citizen science program and the environmental education activities. A qualitative research design (Merriam \& Tisdell, 2015) was used to collect data from semistructured interviews with students after their involvement in WATER Club.

\section{Positionality}

This study was part of a larger CS project, consisting of multiple community organizations and partners, but all engaged in monitoring water quality of Deckers Creek. My research focuses on the local high school, where a local high school teacher created an afterschool citizen science club (WATER club) to participate in this larger project. At the beginning of the project, we recruited students to participate in WATER club, where they had the opportunity to opt-into a larger study. The club was not exclusive and anyone could join or leave as they please, including participants in the study. This research study was centered around the students who consistently participated in club meetings and activities.

In the beginning, my role as a graduate assistant was to write meeting outlines and environmental education activities that were delivered during WATER club. The students participated in place-based water quality activities and sampling. I, along with two other educators on the team, planned all of the activities, led field trips, and facilitated discussions and data collection through a constructivist lens. I was known to my students as the "grad student" from WVU working to help lead the group in data collection and discovery. Now, at the end of this project, my final role was "the researcher" as I interviewed students on their beliefs towards stewardship, knowledge of local water issues, and their perceptions of their ability to "do" 
research. Because my role as an instructor and researcher are intertwined, I acknowledge that I have had an impact on my students, which could influence their responses during the interviews.

As an instructor for about a year, I enjoyed an "insider" look into the WATER club by learning the personalities of my students. I got to know the students both on an individual level and as a group during club meetings and field trips. As someone who has a background in conservation biology and training in environmental education, stewardship and environmental responsibility are the forefront of my personal view. Because this study touches on environmental stewardship, activism and local politics were also mentioned by the students during the study. I facilitated a candid, open platform during causal conservation for such issues to be addressed. Throughout this study, I aimed to conduct an assessment of the club that not only reflects their experience throughout this process but also allows them the opportunity to voice their own views on stewardship.

\section{Site}

The study took place in Morgantown, West Virginia. According to the U.S. Census Bureau estimates, only $20.3 \%$ of the West Virginia's population 25 years or older have a bachelor's degree or higher education, suggesting a potential need for supplemental informal educational experiences (2018) in this state. Citizen science water quality data collection and education will occur on Decker's Creek, a tributary to the Monongahela River which is a major source of municipal water. Decker's Creek is known to have a history of pollution that includes abandoned surface mining and acid mine drainage, trash, combined sewage overflow, and other nonpoint sources (Stewart \& Skousen, 2003). Efforts from a local watershed association (Friends of Deckers Creek (FODC) — another community partner on this project) have been made to monitor and improve the water quality of Deckers Creek through citizen science and remediation 
efforts. This study built upon the existing citizen science program framework provided by this local watershed association. This citizen science program was adapted for an after-school club at a local public high school.

\section{Citizen Science Program}

This study focused on the WATER Club (West Virginia Action Towards Environmental Restoration), which is an afterschool club open to 9th through 12 th grade students. The WATER Club met every 2-3 weeks and served two functions: 1) to act as an extension of a local contributory water quality monitoring program, and 2) to provide environmental education opportunities related to water quality to students. Participants in the club collected water quality and visual data that described Decker's Creek and reported that data on Citsci.org, an online platform for citizen science projects. This data was then reported in an annual newsletter distributed online and to members of the partner watershed association. The WATER Club adopted the Friends of Deckers Creek's citizen science framework, but also incorporated a variety of environmental education activities and lessons to enhance citizen science engagement, allowing participants opportunities to "move" from the current contributory model to a more collaborative model.

The environmental education curriculum used to enhance engagement was composed from a variety of sources focusing on water, watersheds, quality and stewardship (Appendix C). These activities were presented in context of the scientific method (Crall et al., 2012) and used an experiential learning theory (Kolb, 1984) framework for each lesson, which included an experience, reflection, and active conceptualization and experimentation. Other watershed education and monitoring programs have used this framework (i.e. GREEN; Stapp, 2000; Gruver \& Luloff, 2008). The educational activities were modified from the Meaningful Watershed 
Educational Experience program, Project WET, Maryland Explore and Restore Streams Program, Izaak Walton League Save Our Streams, and the Illinois Riverwatch Stream Discovery program. The WATER Club leaders included staff from the Friends of Deckers Creek, and a graduate student and professor from West Virginia University. These leaders provided six sequenced lessons focused on the steps of the scientific method that allowed students to explore the citizen science data and other environmental data such as macroinvertebrate and physical stream habitat features to further assess the health of Deckers Creek. The students then helped plan an educational outreach project that they delivered to the public at a local creek restoration event.

\section{Timeline of Curriculum}

The WATER club was created in February, 2019, by a teacher at a local high school and a participant in this study (Participant 4). The afterschool club met in person every two to three weeks during the school year for a year and a half until March, 2020. Instructors from West Virginia University, including the research team, and the Friends of Deckers Creek led six environmental education lessons focus on the water quality of Deckers Creek, which is located on the school's property. The club met in the teacher's classroom afterschool, then weather permitting, would walk to the creek outside of the school to take water quality samples for the Friends of Deckers Creek citizen science project. Sampling was done at almost every club meeting as a regular monitoring effort for the Friends of Deckers Creek. To teach the students about the creek's health and the importance of citizen science, the students also participated in the environmental education lessons (Appendix C).

The first lesson focused on introducing the students to Deckers Creek and how to sample water quality ( $\mathrm{pH}$, conductivity, salinity, and total dissolved solids) and what constitutes healthy 
water quality (Appendix C: Lesson 1). Students performed a stream bank assessment from Maryland DEP's Explore and Restore curriculum. The second lesson focused on the watershed level impacts to Deckers Creek (such as acid mine drainage, farming, urban runoff, etc.) and had the students use a LaMotte Water Quality test kit to test for parameters such as phosphorus, nitrogen, dissolved oxygen, etc. (Appendix C: Lesson 2) and to explain the results of their tests. These two lessons took place over multiple club meetings in April and May of 2019. The students then had a summer break, where there was one field trip in August, 2019 to West Virginia University's forest near Cooper's Rock State Park to sample water quality at a creek off one of the trails. At this meeting, compared the water quality of the University forest to that of the EPA's standards and reflected on the differences between that location and the high school.

In September 2019, the students were given the opportunity to present what they have learned about the Deckers Creek watershed to other students from the West Virginia University Upward Bound program, which was comprised on high school students from Preston County. Some students from the club planned a meeting at the Outdoor Learning Park in Sabraton, WV, to present on the water quality of Deckers Creek, the major sources of pollution such as acid mine drainage, and on citizen science. This experience is mentioned through some of the student's interviews as "presenting to the Preston county kids." The meeting between the WATER club and the Upward Bound group was entirely planned and facilitated by members of the WATER club, with the support of instructors.

Lesson 3 (Appendix C) took place over the course of three club meetings. Students sampled for macroinvertebrates and collected citizen science data on two occasions at Deckers Creek outside of the high school and on one field trip to the West Virginia Botanic Garden (WVBG). Two club meetings in September, 2019 and October, 2019 were dedicated to sampling 
at the high school, then one meeting in October, 2019 at the WVBG. During the meetings at the high school, the Friends of Deckers Creek demonstrated the West Virginia Department of Environmental Protection's (WVDEP) protocol for sampling macroinvertebrates and students identified and recorded the samples using the WVDEP reporting datasheet. During the meeting at the botanic garden, students sampled for macroinvertebrates in small groups and recorded citizen science data at the site. During the winter of 2019, over multiple meetings, students recorded the data they collected into CitSci.org, the online platform that Friends of Deckers Creek uses to record their citizen science data.

In February 2020, students used CitSci.org and Excel to create visual representations of the data such as tables and graphs to compare data across multiple locations in the Deckers Creek watershed (Appendix C: Lesson 4). In early March 2020, Dr. Smaldone delivered a presentation on effective science communication to the students with a hands-on demonstration from Project WET ("A drop in the bucket" activity) to explain good communication techniques. The students were then asked to work in groups to create a communication project that they could present at the restoration event that was scheduled to occur in May of 2020 but had to be rescheduled due to COVID-19. On March $14^{\text {th }}$, West Virginia public schools were closed until the end of the school year. The WATER club met online for the remainder of the year and into the summer of 2020. In April 2020, a Zoom meeting (zoom.us) was held for a guest speaker, Dr. Jim Anderson from West Virginia University's Division of Forestry and Natural Resources. Dr. Anderson spoke about potential restoration solutions for Deckers Creek such as bio-logs, live stakes and tree plantings (Appendix C: Lesson 5). The club had a Zoom meeting once a month from May to October 2020 to work on their communication projects and to plan a restoration event. Conversations included discussing the budget and materials needed to complete the restoration. 
There was one in-person opportunity presented in June, 2020 where students could come to the Outdoor Learning Park to help pull invasive species and plant native shrubs. Proper social distancing and COVID-19 guidelines from the state were followed, however, only one former student attended.

On October $10^{\text {th }} 2020$, the Deckers Creek Restoration Celebration was held at the Outdoor Learning Park, where the WATER club members (current and former students) presented a poster and a flyer (Appendix D) about the activities of the club, the water quality of Deckers Creek and the restoration plan for Deckers Creek. This event was open to students and family members and social distancing guidelines and COVID-19 protocols from the state of WV were followed. The event was live-streamed on the WATER club's Instagram page as well as the Friends of Deckers Creek. Participants planted sapling trees in the floodplain of Deckers Creek and also install bio-logs, which are biodegradable erosion prevention logs, in the stream bed of Deckers Creek. This event marked the conclusion of the WATER club's environmental education programming.

\section{Participant Sample}

The sample consisted of local high school students that are members of the afterschool group, the WATER Club. High school represents a critical time for students to develop career interests, which makes this age-group of interest to citizen science programs (Hiller \& Kitansas 2014; Baram-Tsabari \& Yarden, 2011). The WATER Club was created by a high school science teacher and another senior student in January of 2019. Students in the club were also asked to participate in the voluntary evaluation study. The sample consisted of high school students that self-selected to participate in the afterschool program and study, representing a purposive sample. A purposive sample was appropriate for this study design because it is aimed at 
understanding the specific bounded case, which is the WATER Club and their citizen science program (Merriam \& Tisdell, 2015). This sample was used to understand the impact of the club and curriculum on the student experiences, which would not be extrapolated to a larger population, which is consistent with case study research. In order to be included in the study, the students obtained parental consent, provided their assent, attended club meetings, participated in citizen science data collection, and participated in an interview. All club members that met the requirements, including past members, were contacted for interviews (total of 14). Members were contacted using Remind, which is a school messaging phone application that allowed students to receive announcements from teachers for a designated class. Most school clubs at this high school had a Remind page at the time of this study, and this phone application was our primary form of contact with the students. We originally had a goal of 10 interviews, which is within the range of five to 25 interview participants as suggested by Brinkmann and Kvale (2015), however, a total of eight students were interviewed due to student availability

(Brinkmann \& Kvale, 2015).

\section{Measures}

Data were collected using semi-structured interviews (Merriam \& Tisdell, 2015). Interviews were conducted according to WVU IRB protocol: 1903511420 and were kept confidential. Interviews took place via Zoom (zoom.us), with audio recording to understand the students' actual outcomes related to citizen science and environmental education. The interview protocol can be found in Appendix A. Questions linked to their appropriate construct with references can be found in Appendix B. Interview questions were based on the participants' experience in WATER Club and some questions were adapted from a study by Ballard, Dixon, and Harris in 2017, that covered similar outcomes to those expected in this study. This study 
used exclusively qualitative uncover participant outcomes in youth, so it served as a starting point for this study, but other studies with interview components were reviewed for questions as well (Price \& Lee, 2013; Knapp \& Poff, 2001; Hiller, 2012; Tommey \& Domroese, 2013; see Appendix B).

\section{Data Collection \& Analysis}

Interviews occurred took place in July, August and October of 2020. Due to the COVID19 pandemic, interviews and club events were adjusted due to safety measures and to be flexible with participants' schedules. Many of the participants were senior high school students in March of 2020, so they had graduated at the time of the interview. Only two of the participants were still students at the high school at the time of the interviews.

All of the data sources relevant to this case study research such as interviews and curriculum (Appendix C) were collected to create a "case study research database" (Merriam \& Tisdell, 2015; Yin 2015). Interviews were transcribed with the aid of the website otter.ai, then reviewed with the audio to correct any discrepancies. Transcripts were then uploaded and coded using Dedoose (dedoose.com), where content analysis was used to review the documents (Bowen, 2009; Stemler, 2001) and to create general themes based on the original research questions. A-priori codes were used to identify specific constructs such as motivation, knowledge and awareness, science self-efficacy and stewardship behavior through deductive coding during the first round. The second round of coding was used to create child codes and emergent themes. Once this process was finished, the results were compared to themes within the existing citizen science literature and theoretical frameworks. 


\section{Limitations}

While the case study research approach has been used for citizen science research in the past, it is not without its limitations. Transferability of this study to a broader context is challenging, but the context and instructional content are provided to give full insight into the case. This small sample of students limits the scope and transferability of the study. An audit trail was used to increase the internal validity of the study since the qualitative interviews are a large portion of the data analyzed in this study (Merriam \& Tisdell, 2015). The researcher positionality was be taken into consideration, as the researcher was part of the group for the duration of the study, attending and leading half of the meetings. 


\section{Chapter 4: Results}

Fourteen students were contacted about participating in an interview, and eight student interviews were completed (response rate of $57 \%$ ). Students were asked a variety of questions related to their participation in the WATER club. Interviews lasted between 20 to 60 minutes depending on the student. Interviews were first coded with a-priori codes related to the key constructs in the research questions - awareness, motivation, knowledge, self-efficacy and stewardship behaviors — and then a second round of coding was used to identify themes.

\section{Motivation}

Motivation to participate in WATER Club or citizen science was defined as "goal-driven inclination to achieve a science or environmental behavior or activity" (Phillips et al. 2018; Peter et al., 2019). Motivations were coded as any goals associated with initially joining the club and continuing or not to participate in the club.

\section{Motivation to join the club linked to interest and potential enjoyment}

Six out of eight students discussed initially joining the club because they were interested in the environment, water quality or the subjects discussed in the club. Students also mentioned initially joining the club to learn about Deckers Creek (1/8), the promise of making an impact (2/8), their teacher's persuasion (2/8), and because of the field trips presented in the club (2/8) (Table 2). One student described their initial decision to join the club because of the field trips presented as an option of the club and continuing to participate for other motivations that arose within the club:

"I was in [teacher's] class and for biology and he told us all about it. And he said that we could go on a field trip to Spruce Knob, and that he said that we would have a lot of field trips. So, I originally joined for the field trips, because all the field trips he was talking 
about sounded really fun. And then I showed up to a few of the meetings and I was kind of hooked because it was so hands-on in the environment. Like it felt like you were actually doing something." - Participant 6

\section{Continued Motivation to Participate}

Five out of eight students also described the real-world applications to the environment and their community, which led them to continue participating in the club. They described what they did in the club as "important", "rewarding", "making a difference" and "doing something productive". Half of students described social goals for continuing to participate in the club, such as making and seeing friends, liking the people in the club, being with "like-minded individuals." "Honestly, I had a lot of fun. The more I came to the meeting things, the more fun it became. To be honest, I didn't have a lot of friends when I first joined junior year, I was kind of like there alone. But whenever we started going out to the creek and exploring things, I made friends and also getting to like, do things hands on, go to the creek and learning all this stuff. I remember coming home, I'd be like, wow, I know this now. Like, I know about acid mine drainage, and things like that. And it felt like I was doing I was making a real difference, but also like learning things. So, I really enjoyed the experience." - Participant 5. 
Table 2.

\section{Motivation Coding Tree}

\begin{tabular}{|l|l|l|}
\hline \multicolumn{1}{|c|}{ Parent Code } & \multicolumn{1}{|c|}{ Child Code } & \# Students \\
\hline Initial Motivation & - Interest in the & $5 / 8$ \\
& environment & \\
& - Make an impact & $2 / 8$ \\
& - Field trips & $2 / 8$ \\
& - Teacher & $2 / 8$ \\
\hline Continued Motivation & - Hands-on, activities & $2 / 8$ \\
& - Social & $4 / 8$ \\
& - Career & $1 / 8$ \\
& - Helping the environment/ & $5 / 8$ \\
& make an impact & $1 / 8$ \\
& - Learning & \\
& &
\end{tabular}

\section{Awareness}

In the context of this study, awareness of environmental issues was defined as a "sensitivity to the total environment and its allied problems and/or issues" (Hungerford \& Volk, 1990, p. 258). Students were asked questions related to their own awareness of environmental issues before and after participating in the club. We were interested in determining their perceived differences between their sensitivity to issues within Deckers Creek before and after participation in the club.

\section{Students aware of water quality issues in Deckers Creek}

Most students described their awareness of the issues of Deckers Creek as having general knowledge that Deckers Creek was "dirty" and has "water issues" or "pollution" (7/8). This information came from general observations of the creek from growing up in Morgantown (2/8) or having their parents (2/8) or family/friends talk with them about the issues of Deckers Creek or be involved in some community group focused on the issues of Deckers Creek (1/8) (Table 3). 
One student, who was recruited by the teacher to help create the club was an exception to this, and described themselves as more aware than most. This student had also previous volunteered with Friends of Deckers Creek and was aware of specific problems associated with the creek, such as acid mine drainage.

“I just knew like general that there were water problems, but I didn't know what it was."

- Participant 8

"But I didn’t really understand what it really meant for water to be healthy."

- Participant 2

\section{Awareness of environmental issues changed as a result of participation}

After participating in WATER Club, all students expressed that their awareness of the problems of Deckers Creek have changed. Students were able to describe at least one specific problem associated with the water quality of Deckers Creek that they did not know before the club. Four out of eight of the students describe being able to communicate the water quality and acid mine drainage issues of Deckers Creek to others. One student was now aware of the responsibility they have to fix the issues.

"I realized; Oh this goes further than I thought." - Participant 4

"I had known that it was like that, but I didn't really understand the extent to which that it was like that and like I didn't understand that cause either being like the mines and the sewage" - Participant 5

“So, I learned- I didn’t know much at all.” - Participant 1

"I wasn't fully aware of the responsibility we have to fix it." - Participant 1 
Table 3.

Awareness Coding Tree

\begin{tabular}{|c|c|c|}
\hline Parent Code & Child Codes & \# Students \\
\hline $\begin{array}{l}\text { Water Quality Issues } \\
\text { Before }\end{array}$ & $\begin{array}{l}\text { - General water pollution } \\
\text { - Acid mine drainage }\end{array}$ & $\begin{array}{l}8 / 8 \\
1 / 8\end{array}$ \\
\hline $\begin{array}{l}\text { Water Quality Issues } \\
\text { After }\end{array}$ & $\begin{array}{l}\text { - Sewage/Fecal Coliform } \\
\text { - Acid Mine Drainage } \\
\text { - Communication } \\
\end{array}$ & $\begin{array}{l}8 / 8 \\
4 / 8\end{array}$ \\
\hline
\end{tabular}

\section{Knowledge}

Students were asked questions related to their knowledge of conducting science, water quality and citizen science throughout the club. Phillips et al. (2018) separates knowledge into three main categories: 1) knowledge and understanding of science content, such as facts or concepts; 2) knowledge and understanding of the science processes or the methodologies used to conduct research; and 3) the knowledge of the Nature of Science or how science is used to generate knowledge. Questions in this study were limited to knowledge and understanding of science content, and knowledge and understanding of the science process or methodologies used to conduct research. Students were not asked questions about the Nature of Science or how science is used to create knowledge, as this was not a topic that was discussed at length within the club.

Students described knowledge related to science content and process.

Content Knowledge. When asked what they learned in the club, the students described information related to science content or facts related to water quality, science processes or related to research and real-world applications of that knowledge. Science content was broken into child codes related to indicators of water quality, watershed issues, data application, citizen science, and stewardship (Table 4). All students described indicators of water quality that were 
discussed in the club, with the most mentioned specific water quality parameter being $\mathrm{pH}(8 / 8)$. Other notable terms and concepts mentioned were: acid mine drainage (4/8), macroinvertebrates (5/8), conductivity (4/8), TDS (3/8), erosion (4/8), temperature (6/8), visual assessments (3/8), turbidity (2/8), salinity (3/8). Six of the students were able to describe watershed level impacts to Deckers Creek. Students also described how the data they learned would be important to use to compare water between multiple locations or watersheds (4/8) or fix other portions of the stream, and (3/8) mentioned using the data to advocate for local bodies of water in local government, groups, laws, etc. All students were able to recall the citizen science protocol that they followed to collect the water quality data. Students were also asked to describe what citizen science and most students described it as a way to help researchers, the community or the environment (4/8) or a process of involving community members in research (4/8):

"Citizen science means to me when an individual who may or may not have, like, a higher affiliation to the scientific community takes it upon themselves to go out into the public and attempt to research or present a scientific idea based on local or immediate, issues in their community." - Participant 2

Science processes. When asked what they should consider when setting up a scientific study or conducting research, students also described knowledge related to science processes. Students described information related to having a guiding question or hypothesis, collecting and sharing data, collecting accurate data, the importance of data in data collection and throughout the study (2/8), working as team, peer review of the findings, communicating the findings of the study with others, and knowing your resources such as the budget, time, people. While all students described knowledge related to science processes, most only mentioned 1 or 2 steps in 
the science process. Students gave multiple ideas related to the process of science, with some students (3/8) approaching the question in a step-wise manner as illustrated below:

"When you're setting up a scientific research project? Well, you'd figure out well, first what you want to know. And then why you want to know it. If you would have, well, you have to figure out a budget because that's important too. You can't just go out and then buy like 15 probes for the water, and then be like, Oh, well, I just took all of that out of my own pocket because that's all expensive. Who's gonna do the research with you? Citizen scientists are usually they mean they're not paid. So, I mean, I guess that's a good way to cut back on costs. But it's just like, all little things. So, you got to put in all your data, how you're going to show your data? Who wants the data? Is it just you? Why do you want the data?..."- Participant 6

\section{Table 4.}

\section{Knowledge Coding Tree}

\begin{tabular}{|l|l|l|}
\hline Parent Codes & Child Codes & \# Students \\
\hline Science Content & - Indicators of Water Quality & $8 / 8$ \\
& - Data Application & $7 / 8$ \\
& o Comparison between & $4 / 8$ \\
& watersheds & $3 / 8$ \\
& O Advocate for local bodies of & \\
& - - Citizen Science & $8 / 8$ \\
& - Watershed Issues & $6 / 8$ \\
& - CS protocol & $8 / 8$ \\
\hline Science processes & - Problem question/hypothesis & $2 / 8$ \\
& - Accurate data & $2 / 8$ \\
& - Study Replication & $2 / 8$ \\
& - Collecting \& sharing data & $2 / 8$ \\
& - Communicate with others & $2 / 8$ \\
& - Study design & $3 / 8$ \\
& - Resources & $2 / 8$ \\
& - Working as a team & $1 / 8$ \\
& - Peer review & $1 / 8$ \\
\hline
\end{tabular}




\section{Science Self-Efficacy}

Self-efficacy describes a person's beliefs about their ability to learn specific content and to perform a specific behavior (Bandura, 1997). According to Phillips et al. (2018), self-efficacy for citizen science "is the extent to which a learner has confidence in his or her ability to participate in a science or environmental activity.” (p. 8) Students were asked questions in relation to their confidence or self-efficacy in "doing science" or performing scientific research or the scientific method before and after the club, their general feeling towards science before and after the club, how they thought of themselves as a scientist or someone who does scientific research, and if they believe they've contributed to science. All of these questions were used to determine if and how the club influenced their self-efficacy towards conducting science or studying study.

\section{Initial self-efficacy related to doing science}

When asked about their confidence in their ability to do science, six out of eight students described an increase in their confidence in their ability to do science or conduct scientific research as a result of participating in WATER club. Students were asked to rate their confidence in "doing science" or performing research on a scale of 1-10 before they joined the club. A one on the scale represented no confidence and a ten on the scale represented having complete confidence compared to a professional. Prior to joining the club, five out of eight of the students described their confidence as between a six and eight. Students who were already confident in their ability to do science cited various reasons such as having science class in school and having to do experiments, labs and the scientific method in school, being interested in science and reading scientific articles (2/8). Some students, however, described some doubts or insecurities related to using science because they had not used science in a real-world application. 
Three students described themselves as not confident in their ability to do science before the club. These students rated their confidence in their ability to do science as a two to three and cited reasons of not using science outside of the classroom, thought they weren't naturally good at science, had no experience using the scientific method, and didn't see themselves as someone who could study science or go into science (Table 5).

\section{Increases to self-efficacy related to WATER club participation}

After participating in the club, all students described an increase in self-efficacy or confidence in their ability to do science. When asked again how they would rate their confidence on a scale of 1 to 10 , students who had a high self-efficacy noted a slight increase of one to two points on the scale, while those who had initial low self-efficacy, described that they would rate themselves higher on the scale. All student self-reported responses after their involvement in the club ranged from a 7 to 9 . This question was used to have them reflect on how the club might have influenced their confidence. The majority of students $(5 / 8)$ described the hands-on experiences related to activities in the club as the reason that their confidence increased such as collecting data, using math, and using the scientific method in the club. Other reasons the students cited a change in confidence were having role models such as instructors (2/8), understanding the process of science (1/8), being able to work with other students $(2 / 8)$, and seeing the real-world application of science to their community (1/8) (Table 5).

\section{Changes in attitudes towards science}

When asked questions related to their attitudes towards studying science before and after the club, the majority of the students responded that they "liked science" (7/8), however only half of the students thought they were "good at science." One student described not liking 
science when they initially joined the club. Two other students expressed that while they were good at science and liked science, they still had an insecurity or doubts related to doing science.

"I think I really liked science, like, I felt positive about doing science. I think there was just some of like, I don't want to say insecurity, but like, I thought maybe I couldn't do everything that I would like me to do, but I like I like science before.”

- Participant 4

When asked to elaborate on their doubts, this student went on to explain her lack of experience as the cause of those feelings.

After participating in the club, seven out of eight students described themselves as "good at science." Students also described science as fun or enjoyable (2/8), less intimidating (2/8), "more attainable" by observing the instructors and seeing them as role models (2/8). Two students described no change to their attitudes towards studying science (Table 5).

I just think I've become a lot more confident in my ability to collect data and to be able to understand what it means in practical terms, because I think, again, the stream quality and being able to see the stream around me is much different than being in a classroom setting where I can't necessarily see those things that aren't in front of me, just something about being able to be in the field connected that for me. It made me- and seeing you [interviewer] do what you're doing or like to seeing other like adults, like kind of modeling the way, because I haven't really had like- my parents aren't in STEM at all. They're not they don't know very much about science. So, it's like having those role models there and people doing like what you want to do. It just makes things seem more achievable. - Participant 4 


\section{Attitudes towards contributing to science}

When asked if they had contributed to science, seven out of eight students reported feeling like they had contributed to science from participating in WATER club (Table 5). Six of those students described that by collecting data for citizen science, they were contributing to science as illustrated below:

"I mean, even one-time collecting data and actually entering it in the system, that's contributing. I mean, whether we did it once or a couple of times, like, it was contributing." - Participant 7

Two students described contributing to science through raising awareness for environmental issues and educating others.

\section{Table 5.}

\section{Self-Efficacy Coding Tree}

\begin{tabular}{|c|c|c|}
\hline Parent Code & Child Code & \# Students \\
\hline $\begin{array}{l}\text { Described change in self- } \\
\text { efficacy }\end{array}$ & $\begin{array}{l}\text { Small increase } \\
\text { Large increase }\end{array}$ & $\begin{array}{l}5 / 8 \\
3 / 8\end{array}$ \\
\hline Influences to confidence before & $\begin{array}{l}\text { Positive } \\
\text { - School/science class prepared me for } \\
\text { the club } \\
\text { - Understood science } \\
\text { - Previous interest in science } \\
\text { Negative } \\
\text { - Never displayed capability } \\
\text { - Didn't think they would be a scientist } \\
\text { - Not sure how to approach science on } \\
\text { own }\end{array}$ & $\begin{array}{l}2 / 8 \\
1 / 8 \\
2 / 8 \\
\\
2 / 8 \\
2 / 8 \\
3 / 8\end{array}$ \\
\hline Influences to confidence now & $\begin{array}{ll}\text { - } & \text { Role models } \\
\text { - } & \text { Understand process of science } \\
\text { - } & \text { Hands on experience } \\
\text { - } & \text { Working others }\end{array}$ & $\begin{array}{l}2 / 8 \\
1 / 8 \\
5 / 8 \\
2 / 8\end{array}$ \\
\hline
\end{tabular}




\begin{tabular}{|c|c|c|}
\hline & $\begin{array}{l}\text { - See application of science to } \\
\text { community }\end{array}$ & $1 / 8$ \\
\hline Attitude towards science & $\begin{array}{l}\text { Before Club } \\
\text { - Liked science } \\
\text { - Insecure/scared } \\
\text { - Didn't like science } \\
\text { - Not good at science } \\
\text { - Good at science } \\
\text { After Club } \\
\text { - Fun/enjoyable } \\
\text { - Less intimidating } \\
\text { - More attainable / anyone can be } \\
\text { - } \text { scientist } \\
\text { - Nood at science } \\
\text { Remained the same }\end{array}$ & $\begin{array}{l}7 / 8 \\
2 / 8 \\
1 / 8 \\
4 / 8 \\
4 / 8 \\
\\
2 / 8 \\
2 / 8 \\
2 / 8 \\
\\
7 / 8 \\
1 / 8 \\
2 / 8\end{array}$ \\
\hline Contributed to science & $\begin{array}{l}\text { Citizen science is contributing to science } \\
\text { - Collecting data } \\
\text { - Raising awareness/educating others }\end{array}$ & $\begin{array}{l}7 / 8 \\
5 / 8 \\
2 / 8\end{array}$ \\
\hline
\end{tabular}

\section{Stewardship Intentions and Behaviors}

Stewardship behavior change in citizen science was defined as "measurable actions resulting from engagement in citizen science, but external from the protocol activities and the specific project based-skills" (Phillips et al., 2018, p. 10). During the interviews, students were asked questions related to any behaviors they might have done outside of the club or in their daily life to help Deckers Creek. External activities include any new activity taken by the students that did not happen during and within the club. For example, in one club activity some of the students communicated their findings of the citizen science project to a group of other students. Presenting those ideas to another group was novel to some students but was not counted as a behavioral change because it took place within the club. Behavioral changes were noted if the behavior was not assigned or suggested by the club and students performed the behavior on their own. 


\section{Actual Behavioral Change}

Most students described new actions they took outside of the club, but one student did not think they had performed any new action outside of the club (1/8) but mentioned other actions within their interviews that demonstrated that they had performed a new behavior (Table 6). All students described at least once where they had spoken to people outside of the club about Deckers Creek, its water quality issues or the club to their peers, their family or co-workers. Two students described picking up trash as a new behavior. One student, who regularly attended club meetings, described that she wrote about the club in her college entrance application essays, spoke about it in her college interviews, and tried to recruit members to the club. The following quotes demonstrate the various behavioral change:

"I mean, usually, you see trash and you know, you think about it, you usually will pick it up, but I definitely, like, look for it now. If that makes sense? If I go somewhere, I'm kind of like looking for it. Not even just trash, but like- I go to waterfalls a lot. It's one of my cousin's, and I like favorite hobbies to do. All over West Virginia. And like, every time I go, you can kind of just tell like- not even acid mine drainage, but you know, the orange color is all over the rocks. And she's like, 'Oh, my gosh, that looks so cool!' And I'm like, 'Oh, yeah, but actually, like, that's not good, you know?'”

\section{- Participant 7}

“Well, one thing I've been doing more is like just talking about Deckers Creek and like creek health in general, which was something I never like, even discussed ever.”

\section{- Participant 1}

"I would like talk to my friend like my college friends would be like, oh yeah, like I'm involved like in this project trying to like help Deckers Creek and they're like, 'Oh like 
what what's wrong with Deckers Creek?' And I'm like, 'Oh, well, there's an abandoned mine that has caused the creek to become more acidic and like just a hostile environment for living organisms and we're trying to like develop a restoration project' and I just like, yeah, generally talk about Deckers Creek." - Participant 4

\section{Behavioral Intent}

Five out of eight students said that they intended to do something in the future to help Deckers Creek (Table 6). These students described volunteering with Friends of Deckers Creek or other advocacy groups.

“ I think I will obviously, probably do more volunteer work as my time as a student and I have thought about when I do I want to go to Friends of Deckers Creek, because they were talking about their volunteer opportunities when we went for a couple field trips and I was interested." - Participant 7

Two students mentioned not intending to take any action to help the creek, and described their reasoning as follows:

"Honestly, like, I never really thought about, I know it needs action, but I don't know. Like, I never thought about me being the one that- I know, I need to, but, like I never really thought about it that much, like me taking the action." - Participant 8

"Um, oh, probably not. I mean, if an opportunity presents itself I'll always be, you know, there to help but I'm not planning on like leading any sort of initiative or anything." Participant 5 
When asked if they plan to take any action to help Deckers Creek outside of the club, one student mentioned the difficulty of doing so because of the current COVID-19 restrictions in West Virginia at the time of the interview:

"Definitely. I think it's hard right now because of the Coronavirus, but it, I mean, I hope that eventually I'll be able to get more involved with the citizen science programs that, with Deckers Creek, and I hope to continue the WATER club when it is more of a realistic option through school." - Participant 6

\section{Potential Stewardship Behaviors}

Students were also asked to describe one or two things that someone could do to help Deckers Creek. More than half of students (5/8) mentioned getting involved with citizen science or collecting citizen science data for the Friends of Deckers Creek. Students described many other actions such as: talking with others about the issues; picking up trash; civic action like voting, petitions to stop sewage from flowing into the creek, keeping up with local legislation; holding a restoration or plantings, and organizing events.

"Well, one thing, I can like continue taking the surveys and helping like monitor the water quality of Decker's Creek, the restoration project would help, potentially. Um, yeah, I think that's about it, like other than that and just like talking to people about it, see if like, they can organize events." - Participant 1 
Table 6.

Behavior Coding Tree

\begin{tabular}{|c|c|c|}
\hline Parent Code & Child Code & \# Students \\
\hline Actual Behaviors & $\begin{array}{l}\text { - Talking to peers/family/others outside } \\
\text { of the club } \\
\text { - Picking up trash } \\
\text { - Researched club topics } \\
\text { - Wrote about club in college essay } \\
\text { - Recruiting members to club } \\
\end{array}$ & $\begin{array}{l}8 / 8 \\
2 / 8 \\
1 / 8 \\
1 / 8 \\
2 / 8\end{array}$ \\
\hline Intended Behaviors & $\begin{array}{l}\text { - Volunteering } \\
\text { - Get involved with advocacy groups } \\
\text { - Stay informed }\end{array}$ & $\begin{array}{l}4 / 8 \\
1 / 8 \\
1 / 8\end{array}$ \\
\hline $\begin{array}{l}\text { Potential stewardship } \\
\text { behaviors }\end{array}$ & $\begin{array}{l}\text { - Talk with others } \\
\text { - Pick up trash } \\
\text { - Citizen Science } \\
\text { - Restoration/plantings } \\
\text { - Civic Action (local legislation, vote, } \\
\text { petition) } \\
\text { - Organize events }\end{array}$ & $\begin{array}{l}2 / 8 \\
4 / 8 \\
5 / 8 \\
3 / 8 \\
3 / 8 \\
1 / 8\end{array}$ \\
\hline
\end{tabular}

\section{Summary}

In summary, participants described a change in motivations, change in awareness of environmental issues of Deckers Creek, gain in knowledge related to science content and science process, change in self-efficacy related to science, and described an actual behavioral change.

Students were able to thoroughly describe water quality and watershed issues in Deckers Creek.

The club had many effects on the participants, some outside of the scope of this study, but overall, the outcomes related to the initial research questions were described and recorded through the interviews, with most outcomes independently described through multiple student interviews. 


\section{Chapter 5: Discussion}

After participating in a collaborative water quality citizen science program, all students described outcomes related to environmental awareness, knowledge of science content and process, motivation, science self-efficacy, and stewardship behavior. The student interviews revealed the extent to which each student participated in the program and while all students had a unique experience with varied participation, there were still many unified themes throughout the interviews that resonate with the literature.

\section{Awareness of environmental issues}

Most students described having an increase in awareness of the environmental issues of Deckers Creek after participating in WATER club. Specifically, their awareness of water quality issues moved beyond that of just "pollution," to specific environmental problems facing Deckers Creek such as acid mine drainage and combined sewage overflow systems. Half of the students also described their awareness of the issues as now being able to explain them to someone else, which demonstrates the degree to which they understand the local environmental impacts to Deckers Creek. This is consistent with the increase in knowledge related to content specifically surrounding Deckers Creek, water quality issues and watershed issues. This increase in knowledge of watershed issues was consistent with the initial club meeting (April, 2019), where there was a PowerPoint presentation from Friends of Deckers Creek about acid mine drainage and Lesson 2 (May, 2019; see Appendix C), which focused on watershed scale problems of Deckers Creek. The regular meeting location of WATER club to take water samples was also located near a Morgantown Utility Board sewer effluent site, which suggest why many students 
discussed sewage as an issue of Deckers Creek. Jordan et al. (2011) also found an increase in awareness related to contextual topics of an invasive species citizen science program. Awareness is linked to knowledge (Hungerford \& Volk, 1990) and described awareness is consistent also with the content knowledge gains in participants. Students also described content and science process knowledge gains throughout the interviews.

\section{Perceived impact on content knowledge}

Topical content knowledge are the facts and concepts related to the citizen science program. Students described many terms that were referred to as indicators of water quality and watershed issues such as "pH" and "acid mine drainage." They were also able to describe different situations where their data would be used, such as by local advocacy groups and to compare water quality of local streams. Students gave their own definitions of citizen science which included helping the community and scientists. They were also able to explain the stepwise protocol of collecting the scientific data. This is consistent with much of the literature that suggests real knowledge gains can occur from participating in citizen (Crall et al., 2012; Jordan et al., 2011). This is, of course, generally true for participants or volunteers that do not have sufficient knowledge of the program beforehand, which was found by Overdevest et al. (2004). This program relied on the use of environmental education during meetings and sampling (Appendix C), which discussed all of these topics through experiential learning opportunities and consistent group discussions which could have resulted in the knowledge gains described through the interviews.

\section{Perceived impact on knowledge of science processes}

Science process is described as "understanding the methodologies that scientists use to conduct research" (Philips et al. 2018, p. 9). Students described various science processes when 
asked what they learned about conducting research. These responses were varied, potentially because vagueness of the question, "What are some important things to think about when setting up a scientific research project?" There appeared to be a lot of interpretations of "setting up a scientific research project," and some students described their thought process using questions. Key steps in the scientific method and in organizing research in general were reported by students. Some students mentioned the budget and personnel, and some described the research question and collecting data. Students learned information about being scientists and discussed various organization and planning issues that researchers face when setting up a study. This was informally discussed throughout the program, with one notable meeting where we included students in our discussion of the budget for the fall restoration project. In this Zoom meeting, we showed students the budget breakdown and asked for their opinion on what the club needed to purchase to complete the communication and restoration goals for the day. The literature suggests that few projects measure science process as an outcome of knowledge or at all (Philips et al., 2018) and some studies that have attempted to measure science process (Jordan et al., 2011; Brossard et al., 2005) found no increase in science process knowledge. A clear linkage between CS project objectives, participant training and tasks, and appropriately linked outcomes is needed to ensure project success. Further study on the construction of science process knowledge through citizen science is needed.

\section{Student Motivations Changed Throughout the Program}

The majority of students described intrinsic motivations (5/8) such as having an interest in the environment, which they cited as their primary reason for joining the club. The club was originally described to them as an environmental club. Students were recruited to the club through a teacher and one of the other club members, which explains the few students that cited 
their teacher as the primary reason they joined the club. Few students cited other motivations for joining the club such as the potential to make an impact and the promise of field trips. All of these intrinsic motivations are consistent with citizen science research (Geoghegan et al., 2016), which suggests that volunteers' motivations change throughout the course of a project (Rotman et al., 2012). When asked why they decided to continue to participate, most students described a realization that they were going to help the environment or make a "real-world" impact. Some students described having social goals such as making friends, career goals, and learning. Current motivation frameworks for citizen science are based on those of volunteering, because citizen science is a volunteer activity. Finkelstein (2009) described both intrinsic and extrinsic motivations for volunteering in general, such as: understanding, values, social, enhancement, career, protective. In citizen science, the most common motivations found in previous research are altruistic, such as caring for a resource or the environment (West \& Pateman, 2016; Geoghegan et al., 2016; Domroese \& Johnson, 2017). For the students in this club, motivations changed over time when they learned the potential to make a real-work impact, which is consistent within the volunteering literature and citizen science literature as well (West \& Pateman, 2016).

\section{Perceived impact on science self-efficacy}

Self-efficacy describes a person's beliefs about their ability to learn specific content and to perform a specific behavior (Bandura, 1997). According to Phillips et al. (2018, p. 8), selfefficacy for citizen science "is the extent to which a learner has confidence in his or her ability to participate in a science or environmental activity." The four main sources of self-efficacy are mastery experiences, vicarious experiences, social persuasion and physiological states (Bandura, 1997). Students cited both positive and negative influences on their science self-efficacy or their 
confidence to "do science" or conduct research. They described that school and science class had prepared them for the club (mastery experience), so they felt they understood science and they had previous interest in science. Some students described both being good at science, but not being confident in their abilities to conduct scientific research, while others described just not being good at research. Students cited reasons such as never displaying their capability, not being sure how to approach science on their own, and that didn't think they would be a scientist.

After participating in WATER club, all students described changes to their self-efficacy. The students also described changes in their attitudes about studying science and their feelings of how "good" they were at science. Many students liked science before their involvement in the club, but only half felt like they were good at science. Because of mastery experiences presented throughout the club, their attitudes towards science changed to having seven out of eight students feeling like they were good at science. The various influences they attributed to that change were hands-on experience (mastery experience), having adults model the behavior, in particular, women instructors (social persuasion), working with others (vicarious experiences), feeling like the understood the process of science, seeing it in the community, and the feeling that they had contributed to science (Bandura, 1997). This is consistent with other studies of self-efficacy on youth in citizen such as Hiller et. al, 2012 which showed self-efficacy gains after participation in a horseshoe crab citizen science program. Other research has suggested that self-efficacy is important for environmental citizenship (Berkowitz et al., 2005) along with knowledge, awareness, skills and opportunity to bring change. Interestingly, Price and Lee found a decrease in the self-efficacy of their participants after participating in an online citizen science program, attributing the change to the realization of how much they didn't know previously about the topic (2013). A few students in this study also noted they realized that they knew less than they 
previously thought, but potentially because of the other experiences in the club that allowed for other efficacy processes to form, such as mastery experiences, a decrease in self-efficacy wasn't described. Various factors of WATER club such as the hands-on citizen science experience, the support from the teacher and instructors, and the ability for students to meet and make friends were all described as factors that influenced the students' self-efficacy.

\section{Stewardship Behavior}

\section{Actual Behaviors}

Phillips et al. (2018) described various actual stewardship behaviors that could result from citizen science in categories such as global behaviors (minimize ecological footprint), place-based behaviors (picking up trash, outreach), new participation in science or environmental activities, community or civic action, and transformative life-style changes (owning a hybrid vehicle, becoming vegetarian). Students in this study discussed two new behaviors that they attributed to their participation in the WATER club, which were communicating and talking with peers, family and co-workers about the environmental issues of Deckers Creek and picking up trash. According to Phillip's categorization of behavioral changes from citizen science, both of these behaviors would be considered place-based behaviors (2018). These results are consistent with other studies that assessed behavioral change in participants. Jordan et al., (2011) minimal behavior changes towards invasive species, even with an increase of knowledge and awareness, but most participants after the program spoke with others about invasive species, which is consistent with the results of this study. This result is also consistent with Overdevest et al., 2004, which found that the majority of participants in a stream monitoring program either engaged in personal research or reading on water quality issues after their involvement in the program or talked with neighbors about water quality issues. Lewandowski and Oberhauser 
found through survey research an increase in conservation related behaviors associated with an increase of knowledge of how to perform those behaviors (2017). Students did not explicitly state what led to the behavioral change in communicating with others about water quality issues of Deckers Creek, but an increase in knowledge of those issues as well as the many opportunities presented throughout the club to discuss and present on their knowledge (see Lesson 5; Appendix C) could have aided in this behavioral development. Lewandowski and Oberhauser also mention the solitary nature of citizen science and the majority of survey respondents did not participant in a group setting, which is unlike this study (2017). The nature of group sampling could have also aided in the development of communication skills. While there were few behaviors beyond communicating and picking up trash, students noted other intended behaviors and knowledge related to additional potential stewardship behavior.

\section{Intended Behaviors}

Half of the students mentioned volunteering with Friends of Deckers Creek as an intended behavior in the future to help Deckers Creek, while one student mentioned staying informed on potential issues and getting involved in local advocacy groups. While participating in citizen science can lead to new participation in behaviors, many studies have described a discrepancy that exists between actual behaviors and intended behaviors. Toomey and Domerose (2013) cited linkages between conservation behaviors and citizen science from applying an intervention based on the Theory of Planned Behavior (Azjen, 1991). Hungerford and Volk's (1990) model stress the linkages of environmental sensitivity (awareness), attitude (can be seen through the self-efficacy responses), knowledge, skill and locus of control (can be seen through the self-efficacy responses) that contribute to citizenship behavior. 
It should be noted that at the time of the interviews and of writing this manuscript, West Virginia COVID-19 regulations prevent gathering of large groups, which could act as a barrier for the participants to act on these intended behaviors.

\section{Knowledge of stewardship behaviors}

Students were also asked to describe a few actions that people could do to help Deckers Creek. All students responded with at least one activity. Some of these activities were local, such as picking up trash, talking with others to raise awareness, planting trees and restoring the stream bank organizing events, participating in citizen science, and civic actions. Students mostly describe place-based behaviors (picking up trash, planting trees and restoring streams, talking with others; Philips et al., 2018). They did not describe any global or transformative lifestyle changes (Philips et al., 2018). Because the club centered on place-based solutions to the environmental issues in Deckers Creek and worked towards a final hands-on restoration project, their responses were consistent with the discussions covered in the club. Civic action was not a topic or focus of the club, so these responses could have been from prior knowledge, informal discussions that could have taken place within the club, or from one student's own interest in civic engagement. However, knowledge of all this information is consistent with citizen science literature that suggests these are the main ways that people exhibit a behavior change (Phillips et al., 2018). Knowledge of these behaviors also helps to aid in performing the behavior according to the environmental citizenship model (Hungerford \& Volk, 1990). Some of these behaviors were discussed with students during their creation of communication projects (Lesson 4 of the environmental education curriculum, Appendix C) and were reflected in the action item list made by one student (Appendix D), however not all students were involved in creating this project, so educational opportunities might have been lost on those that were not involved. 


\section{Study Limitations}

This study had several limitations related to the study timeline and unforeseen issues due to COVID-19 and the interview process and therefore the outcomes. First, the interview process, which was originally scheduled for May 2020 after the restoration event, had to be moved due to COVID restrictions. In March 2020, all students in West Virginia schools transitioned to online learning, which limited the contact the researchers had with the students. After-school clubs were not allowed to meet, which resulted in the WATER club moving to virtual, Zoom meetings. As a result of this move, the majority of the students in the club "fell off" or did not continue to come to meetings. This limited our contact with the students greatly. Five out of the eight students interviewed were those that did not attend the virtual meetings of the club after they had gone online, due to various reasons. The restoration event which was originally scheduled for May 2020, was moved to October 2020. This altered the timeline of interviews, so students were either interviewed before the restoration event in July-August 2020 (five students) or after the event in October 2020 (three students).

Another potential limitation was the interview protocol as well. Students were asked to reflect on their experiences in WATER club in a summative interview. The interview itself consisted of many questions and some knowledge related questions had students reflect back to their time in the club, which could have been six months to a year previous. While most students answered these questions thoroughly, many students mentioned difficulty answering some questions because of the length of time that had passed between the club activities and the interview, which could have introduced the possibility of the recall effect (Raphael, 1987). The length of the interview could have also potentially resulted in diminished quality of answers, however, most participant's answers to the questions were fully formed and thorough. Only one 
student had shorter, more concise answers to the questions throughout the entirety of the interview.

Because the students were familiar with the interviewer for roughly a year to year and a half, there could have potentially been a halo effect (Feely, 2002) which could have influenced their answers to the questions about WATER club based on the respondent's inherent biases towards the researcher. Social desirability bias (Nederhof, 1985) could have also influenced participants' responses, which is the tendency of respondents to deny undesirable traits or overestimate the likelihood that they would perform a desirable action (Chung \& Monroe, 2003). In order to combat this, the importance of honesty at the beginning of the interview was emphasized by the interviewer as well as probing questions to fully understand the rationale behind their answer and substantiate their claims.

\section{Implications}

The results of this study demonstrate the impact of a long-term, water quality monitoring citizen science program for high school youth. Students described outcomes related to: motivation (Geoghegan et al., 2016; Rotman et al., 2012; West \& Pateman, 2016; Domroese \& Johnson, 2017), awareness and knowledge (Jordan et al., 2011; Hungerford \& Volk, 1990; Crall et al., 2012; Overdevest et al., 2004; Brossard et al., 2005), self-efficacy (Hiller et al., 2012; Berkowitz et al., 2005; Price \& Lee, 2013) and behavior (Jordan et al., 2011; Overdevest et al., 2004; Lewandowski \& Oberhauser, 2017) that corroborates existing literature. Student interviews gave explanations as to what elements of the program were successful to the students such as: the environmental education activities that contribute to gains in content and process knowledge; the hands-on nature of program, working in groups and having instructors (and particularly female) role models that contributed to an increase in self-efficacy; the "real-world" 
impact of the club and the potential to make social connections that aided in sustaining continued motivation in the program; the heightened awareness of local environmental issues from engaging in the curriculum and observing the first hand impacts to the environment through citizen science; and the actual behavior change of all participants of speaking to others that was also developed through group discussion and communication projects. When designing a program for youth, future program managers can use elements of this program as a starting point to create an engaging water quality program for youth. The results of this study could also influence formal and non-formal STEM education. By integrating elements of environmental education and citizen science, educators would be facilitating "real-world" connection to science that could increase engagement in the sciences as well as increased science self-efficacy, motivation, awareness of local issues, increase communication skills and potentially civic action. Creating connections with local community partners to achieve this would also lead to a sustained program that could foster these outcomes as well as provide additional role models of scientists and instructors that could affect science self-efficacy.

\section{Future Directions}

While the scope of this study did not include outcomes such as science inquiry skills (Philips et al., 2018) or environmental science agency (Ballard et al., 2017), there was some evidence to suggest that these outcomes could have occurred or were in the process of forming for some of the students. Some students were able to describe knowledge related to science process in which they cited steps to the scientific method as things that are important to consider when conducting research. While this might demonstrate knowledge about the science process, actual science inquiry skills are those that can be evaluated through observation and skills assessments administered within the citizen science program or embedded assessments (Becker- 
Klein et al., 2016). Due to the constraints of the project and the unforeseen circumstances, we were unable to assess science inquiry skills, but future research working with youth in an environmental education and citizen science setting could focus on understanding the inquiry skills gained through embedded assessments as suggested by Becker-Klein et al. in 2016.

Future studies should also look at the similarities between citizen science and environmental education operations and evaluation to unify evaluation outcomes across both. Examining the long-term impacts of environmental education and citizen science in both a formal and non-formal setting would help to understand the impacts of these programs in and outside of the classroom. Future studies could use a mixed methods design to understand the exact experiences that influence citizen science outcomes in youth and could focus on more longitudinal programs to understand outcomes over time. Studies focused on cross-case study examinations of outcomes could better illustrate their impact on students and a study of multiple water quality monitoring citizen science programs that include youth could be a starting point.

\section{Conclusion}

This study reflects the potential of citizen science and environmental education to impact youth motivation, awareness, knowledge, self-efficacy and stewardship behavior. Youth are a potential large audience for citizen science programs, as they are easily accessible and often a classroom teacher is using citizen science to supplement STEM curriculum. Because of this, citizen science should focus more on elements that contribute to youth development and educational goals as outcomes, incorporating youth voices and experiences as well (Ballard et al., 2017; Harris et al., 2017). Understanding youths' perspectives and experiences through citizen science can allow program managers and project designer to make projects that can achieve higher level citizen science outcomes. 


\section{References}

Aivelo, T., \& Huovelin, S. (2020). Combining formal education and citizen science: a case study on students' perceptions of learning and interest in an urban rat project. Environmental Education Research, 26(3), 324-340. https://doi.org/10.1080/13504622.2020.1727860

Azjen, I. (1991). The theory of planned behavior. Organizational behavior and human decision processes, 50(2), 179-211.

Ballard, H. L., Dixon, C. G., \& Harris, E. M. (2017). Youth-focused citizen science: Examining the role of environmental science learning and agency for conservation. Biological Conservation, 208, 65-75. https://doi.org/10.1016/j.biocon.2016.05.024

Bandura, A. (1997). Self-efficacy and health behaviour. Cambridge handbook of psychology, health and medicine. Cambridge University Press.

Baram-Tsabari, A., \& Yarden, A. (2011). Quantifying the gender gap in science interests. International Journal of Science and Mathematics Education, 9(3), 523-550.

Becker-Klein, R., Peterman, K. and Stylinski, C., (2016). Embedded Assessment as an Essential Method for Understanding Public Engagement in Citizen Science. Citizen Science: Theory and Practice, 1(1), 8. DOI: http://doi.org/10.5334/cstp.15

Bela, G., Peltola, T., Young, J.C., Balázs, B., Arpin, I., Pataki, G., Hauck, J., Kelemen, E., Kopperoinen, L., Van Herzele, A., Keune, H., Hecker, S., Suškevičs, M., Roy, H.E., Itkonen, P., Külvik, M., László, M., Basnou, C., Pino, J. and Bonn, A. (2016), Learning and the transformative potential of citizen science. Conservation Biology, 30, 990999. https://doi.org/10.1111/cobi.12762

Bird, E. B. (2019). Driven by data? Youth learning science for environmental and civic action 
through community and citizen science. (Publication No. AAT 13902298) [Doctoral dissertation, University of California, Davis]. ProQuest Dissertations Publishing.

Bombaugh, R. (2000). From citizen scientists to engineers. Journal of Professional Issues in Engineering Education and Practice, 126(2), 64-68.

Bonney, R., Cooper, C. B., Dickinson, J., Kelling, S., Phillips, T., Rosenberg, K. V., \& Shirk, J. (2009a). Citizen science: a developing tool for expanding science knowledge and scientific literacy. BioScience, 59(11), 977-984. https://doi.org/10.1525/bio.2009.59.11.9

Bonney, R., Ballard, H., Jordan, R., McCallie, E., Phillips, T., Shirk, J., and Wilderman, C. C. (2009b). Public Participation in Scientific Research: Defining the Field and Assessing Its Potential for Informal Science Education. A CAISE Inquiry Group Report. Center for Advancement of Informal Science Education (CAISE). https://www.informalscience.org/sites/default/files/PublicParticipationinScientificResearc h.pdf

Bonney, R., Phillips, T. B., Enck, J., Shirk, J., \& Trautmann, N. (2014). Citizen science and youth education. National Research Council Committee on Out-of-School Time STEM. National Research Council. https://sites.nationalacademies.org/cs/groups/dbassesite/documents/webpage/dbasse_089 993.pdf

Bonney, R., Shirk, J. L., Phillips, T. B., Wiggins, A., Ballard, H. L., Miller-Rushing, A. J., \& Parrish, J. K. (2014). Next steps for citizen science. Science, 343(6178), 1436-1437. https://doi.org/10.1126/science.1251554 
Bonney, R., Phillips, T. B., Ballard, H. L., \& Enck, J. W. (2016). Can citizen science enhance public understanding of science? Public Understanding of Science, 25(1), 2-16. https://doi.org/10.1177/0963662515607406

Bowen, G. A. (2009). Document analysis as a qualitative research method. Qualitative Research Journal, 9(2), 27. https://doi.org/10.3316/QRJ0902027

Brinkmann, S., \& Kvale, S. (2015). Interviews: Learning the craft of qualitative research interviewing. Sage Publications.

Capdevila, A. S. L., Kokimova, A., Ray, S. S., Avellán, T., Kim, J., \& Kirschke, S. (2020). Success factors for citizen science projects in water quality monitoring. Science of The Total Environment, 137843. https://doi.org/10.1016/j.scitotenv.2020.137843

Chung, J., \& Monroe, G. S. (2003). Exploring social desirability bias. Journal of Business Ethics, 44(4), 291-302. https://doi.org/10.1023/A:1023648703356.

Crall, A. W., Jordan, R., Holfelder, K., Newman, G. J., Graham, J., \& Waller, D. M. (2012). The impacts of an invasive species citizen science training program on participant attitudes, behavior, and science literacy. Public understanding of Science, 22(6), 745-764. https://doi.org/10.1177/0963662511434894

Conrad, C. C., \& Hilchey, K. G. (2011). A review of citizen science and community-based environmental monitoring: issues and opportunities. Environmental monitoring and assessment, 176(1-4), 273-291. https://doi.org/10.1007/s10661-010-1582-5

Dickinson, J. L., Shirk, J., Bonter, D., Bonney, R., Crain, R. L., Martin, J., Phillips, T. \& Purcell, K. (2012). The current state of citizen science as a tool for ecological research 
and public engagement. Frontiers in Ecology and the Environment, 10(6), 291-297. https://doi.org/10.1890/110236

Domroese, M. C., \& Johnson, E. A. (2017). Why watch bees? Motivations of citizen science volunteers in the Great Pollinator Project. Biological Conservation, 208, 40-47. https://doi.org/10.1016/j.biocon.2016.08.020

Driven to Discover. (n.d.). University of Minnesota Extension. Retrieved from https://extension.umn.edu/environmental-education-and-community-science/drivendiscover

Druschke, C. G., \& Seltzer, C. E. (2012). Failures of engagement: Lessons learned from a citizen science pilot study. Applied Environmental Education \& Communication, 11(3-4), 178188. https://doi.org/10.1080/1533015X.2012.777224

Evans, C., Abrams, E., Reitsma, R., Roux, K., Salmonsen, L., \& Marra, P. P. (2005). The neighborhood nestwatch program: participant outcomes of a citizen-science ecological research project. Conservation Biology, 19(3), 589-594. https://doi.org/10.1111/j.15231739.2005.00s01.x

Feeley, T. (2002). Evidence of halo effects in student evaluations of communication instruction. Communication Education, 51(3), 225-236. https://doi.org/10.1080/03634520216519

Friedman, AJ, Allen, S, Campbell, PB, Dierking, LD, Flagg, BN, Garibay, C, Korn, R, Silverstein, G and Ucko, DA. (2008). Framework for evaluating impacts of informal science education projects. National Science Foundation Workshop. https://www.informalscience.org/sites/default/files/Eval_Framework.pdf 
Fuccillo, K.K., Crimmins, T.M., de Rivera, C.E. and Elder, T.S., (2015). Assessing accuracy in citizen science-based plant phenology monitoring. International journal of biometeorology, 59(7), 917-926. https://doi.org/10.1007/s00484-014-0892-7

Grudens-Schuck, N., \& Sirajuddin, Z. (2019). Social impacts of citizen science water monitoring programs. Journal of Soil and Water Conservation, 74(3), 49A-54A. https://doi.org/10.2489/jswc.74.3.49A

Gruver, J., \& Luloff, A. E. (2008). Engaging Pennsylvania teachers in watershed education. The Journal of Environmental Education, 40(1), 43-54. https://doi.org/10.3200/JOEE.40.1.43-54

Geoghegan, H., Dyke, A., Pateman, R., West, S. \& Everett, G. (2016). Understanding motivations for citizen science. Final report on behalf of UKEOF, University of Reading, Stockholm Environment Institute (University of York) and University of the West of England. http://www.ukeof.org.uk/resources/citizen-scienceresources/MotivationsforCSREPORTFINALMay2016.pdf

Harris, E. M. (2017). Examining teacher framing, student reasoning, and student agency in school-based citizen science. (Publication No. 10599053). [Doctoral Dissertation, University of California, Davis]. ProQuest Dissertations Publishing.

Hiller, S.E. (2012). The impact of a citizen science program on student achievement and motivation: A social cognitive career perspective. (Publication No. 3547088). [Doctoral Dissertation, George Mason University.] ProQuest Dissertations Publishing. 
Hiller, S. E., \& Kitsantas, A. (2014). The effect of a horseshoe crab citizen science program on middle school student science performance and STEM career motivation. School Science and Mathematics, 114(6), 302-311. https://doi.org/10.1111/ssm.12081

Hungerford, H. R., \& Volk, T. L. (1990). Changing learner behavior through environmental education. The journal of environmental education, 21(3), 8-21. https://doi.org/10.1080/00958964.1990.10753743

Jordan, R. C., Ballard, H. L., \& Phillips, T. B. (2012). Key issues and new approaches for evaluating citizen-science learning outcomes. Frontiers in Ecology and the Environment, 10(6), 307-309. https://doi.org/10.1890/110280

Jordan, R. C., Gray, S. A., Howe, D. V., Brooks, W. R., \& Ehrenfeld, J. G. (2011). Knowledge gain and behavioral change in citizen-science programs. Conservation biology, 25(6), 1148-1154. https://doi.org/10.1111/j.1523-1739.2011.01745.x

Knapp, D., \& Poff, R. (2001). A qualitative analysis of the immediate and short-term impact of an environmental interpretive program. Environmental Education Research, 7(1), 55-65. https://doi.org/10.1080/13504620124393

Kolb, D. A. (1984). Experiential Learning: Experience as the source of learning and development. New Jersey: Prentice Hall

Kountoupes, D. L., \& Oberhauser, K. (2008). Citizen science and youth audiences: educational outcomes of the Monarch Larva Monitoring Project. Journal of Community Engagement and Scholarship, 1(1), 5. 
Lewandowski, E. J., \& Oberhauser, K. S. (2017). Butterfly citizen scientists in the United States increase their engagement in conservation. Biological Conservation, 208, 106-112. https://doi.org/10.1016/j.biocon.2015.07.029

Liu, X. (2009). Beyond science literacy: Science and the public. International Journal of Environmental and Science Education, 4(3), 301-311.

McKinley, D.C., Miller-Rushing, A.J., Ballard, H.L., Bonney, R., Brown, H., Cook-Patton, S.C., Evans, D.M., French, R.A., Parrish, J.K., Phillips, T.B. \& Ryan, S.F., (2016). Citizen science can improve conservation science, natural resource management, and environmental protection. Biological Conservation. 208, 15-28. https://doi.org/10.1016/j.biocon.2016.05.015

Merriam, S. B. (2002). Introduction to qualitative research. Qualitative research in practice: Examples for discussion and analysis. John Wiley \& Sons Inc.

Merriam, S. B., \& Tisdell, E. J. (2015). Qualitative research: A guide to design and implementation. John Wiley \& Sons Inc.

Miller-Rushing, A., Primack, R., \& Bonney, R. (2012). The history of public participation in ecological research. Frontiers in Ecology and the Environment, 10(6), 285-290. https://doi.org/10.1890/110278

National Academies of Sciences, Engineering, and Medicine. 2018. Learning through citizen science: enhancing opportunities by design. The National Academies Press. https://doi.org/10.17226/25183.

National Research Council. (1996). National science education standards. Washington, DC: National Academy of Sciences. https://doi.org/10.17226/4962. 
National Research Council. (2012). A framework for K-12 science education: Practices, crosscutting concepts, and core ideas. National Academies Press. https://doi.org/10.17226/13165.

National Science Board. (2002). Science and technology: Public attitudes and public understanding. Science \& Engineering Indicators. U.S. Government Printing Office. https://www.nsf.gov/statistics/2018/nsb20181/assets/404/science-and-technology-publicattitudes-and-understanding.pdf

National Water Quality Monitoring Council. (n.d.). Retrieved September 11, 2020, from https://acwi.gov/monitoring/vm/

Nederhof, A. J. (1985). Methods of coping with social desirability bias: A review. European journal of social psychology, 15(3), 263-280. https://doi.org/10.1002/ejsp.2420150303

Overdevest, C., Orr, C. H., \& Stepenuck, K. (2004). Volunteer stream monitoring and local participation in natural resource issues. Human Ecology Review, 177-185.

Peter, M., Diekötter, T., \& Kremer, K. (2019). Participant outcomes of biodiversity citizen science projects: a systematic literature review. Sustainability, 11(10), 2780. https://doi.org/10.3390/su11102780

Phillips T, Ferguson M, Minarchek M, Porticella N \& Bonney R (2014) User's Guide for Evaluating Learning Outcomes in Citizen Science. Ithaca, NY: Cornell Lab of Ornithology.

Phillips, T., Bonney, R., \& Shirk, J. (2012). What is our impact. Citizen science: Public participation in environmental research, 82-95. 
Phillips, T. (2017). Engagement and learning in environmentally-based citizen science: A mixed methods comparative case study. [Doctoral Dissertation, Cornell University]. eCommons, Cornell University. https://doi.org/10.7298/X4NSOS2H

Phillips, T., Porticella, N., Constas, M., \& Bonney, R. (2018). A framework for articulating and measuring individual learning outcomes from participation in citizen science. Citizen Science: Theory and Practice, 3(2), 1-19. https://doi.org/10.5334/cstp.126

Phillips, T. B., Ballard, H. L., Lewenstein, B. V., \& Bonney, R. (2019). Engagement in science through citizen science: Moving beyond data collection. Science Education, 103(3), 665690. https://doi.org/10.1002/sce.21501

Price, C. A., \& Lee, H. S. (2013). Changes in participants' scientific attitudes and epistemological beliefs during an astronomical citizen science project. Journal of Research in Science Teaching, 50(7), 773-801. https://doi.org/10.1002/tea.21090

Raphael, K. (1987). Recall bias: a proposal for assessment and control. International journal of epidemiology, 16(2), 167-170. https://doi.org/10.1093/ije/16.2.167

Rotman, D., Preece, J., Hammock, J., Procita, K., Hansen, D., Parr, C., ... \& Jacobs, D. (2012, February). Dynamic changes in motivation in collaborative citizen-science projects. In Proceedings of the ACM 2012 conference on computer supported cooperative work (pp. 217-226). https://doi.org/10.1145/2145204.2145238

Shirk, J. L., H. L. Ballard, C. C. Wilderman, T. Phillips, A. Wiggins, R. Jordan, E. McCallie, M. Minarchek, B. V. Lewenstein, M. E. Krasny, and R. Bonney. 2012. Public participation in scientific research: a framework for deliberate design. Ecology and Society 17(2), 29. DOI: $\underline{\text { http://dx.doi.org/10.5751/ES-04705-170229 }}$ 
Stapp, W. B. (1969). The concept of environmental education. Environmental Education, 1(1), 30-31. https://doi.org/10.1080/00139254.1969.10801479

Stapp, W. B. (2000). Watershed education for sustainable development. Journal of Science Education and Technology, 9(3), 183-197. https://doi.org/10.1023/A:1009430215477

Stemler, S. (2000). An overview of content analysis. Practical assessment, research, and evaluation, 7(1), 17. https://doi.org/10.7275/z6fm-2e34

Stepenuck, K. F., \& L. Green. 2015. Individual- and community-level impacts of volunteer environmental monitoring: a synthesis of peer-reviewed literature. Ecology and Society 20(3), 19. http://dx.doi.org/10.5751/ES-07329-200319

Stewart, J., \& Skousen, J. (2003). Water quality changes in a polluted stream over a twenty-fiveyear period. Journal of environmental quality, 32(2), 654-661. https://doi.org/10.2134/jeq2003.6540

Thompson, S., Bonney, R., Trant, J., \& Bearman, D. (2007). Evaluating the impacts of participation in an online citizen science project: A mixed-methods approach. Museums and the Web. Archives and Museum Informatics, 187-199. https://www.archimuse.com/mw2007/papers/thompson/thompson.html

Toomey, A. H., \& Domroese, M. C. (2013). Can citizen science lead to positive conservation attitudes and behaviors?. Human Ecology Review, 50-62. https://www.jstor.org/stable/24707571

Trautmann, N. M. (Ed.). (2013). Citizen science: 15 lessons that bring biology to life, 6-12. NSTA Press. 
Trumbull, D. J., Bonney, R., Bascom, D., \& Cabral, A. (2000). Thinking scientifically during participation in a citizen-science project. Science education, 84(2), 265-275. https://doi.org/10.1002/(SICI)1098-237X(200003)84:2<265::AID-SCE7>3.0.CO;2-5

U.S. Census Bureau QuickFacts: West Virginia. (2018). Retrieved September 30, 2020, from https://www.census.gov/quickfacts/fact/table/WV/EDU685218

van der Velde, T., Milton, D. A., Lawson, T. J., Wilcox, C., Lansdell, M., Davis, G., Perkins, G. \& Hardesty, B. D. (2017). Comparison of marine debris data collected by researchers and citizen scientists: Is citizen science data worth the effort?. Biological conservation, 208, 127-138. https://doi.org/10.1016/j.biocon.2016.05.025

Wals, A. E., Brody, M., Dillon, J., \& Stevenson, R. B. (2014). Convergence between science and environmental education. Science, 344(6184), 583-584. https://doi.org/10.1126/science.1250515

Wiggins, A., \& Crowston, K. (2011). From conservation to crowdsourcing: A typology of citizen science. 44th Hawaii international conference on system sciences (pp. 1-10). doi: 10.1109/HICSS.2011.207.

Yin, R. K. (2015). Case study research and applications: Design and methods. Sage publications. 


\section{Appendix A: Interview Protocol}

Introduction:

"First, thank you for participating in this voluntary interview. It should take about 15-20 minutes. Your answers are going to be used to help improve the project you have been participating in, as well as in a graduate student degree. The questions deal with your experience in the WATER Club. This interview is going to be recorded and will be as confidential as possible, meaning your name will not be attached to your answers. Please take your time and answer these questions as honestly as you can. You can skip any question or stop the interview at any point, just let me know.

The purpose of this interview is to understand the impact of the WATER Club on you and what you might have learned as a result of participating in the club. If you have any questions during the interview, please do not hesitate to ask. Are you ready to begin?"

\section{ID Number:}

"Before we begin, please create an ID number.

Your ID number is the two digits that represent your birth month, the two digits that represent your birth day, and the initials of your first, middle, and last name. So if your birthday is March 5 (03/05), and your name is Daniel John Smith, then your ID number would be 0305djs."

\section{Questions:}

First, let's talk about your involvement in WATER Club...

1. How long have you been a member of the club?

2. How often do you come to WATER Club meetings?

3. What do you feel your role is in WATER club?

2. Why did you initially join the club?

1. Why did you continue to participate or not?

3. Describe for me what you did in WATER club?

1. Tell me about some of the activities you did in WATER Club?

2. Did you participate in any field trips?

3. Did you get a chance to talk about or present your work or ideas to anyone outside the Club? What was that like?

4. What does citizen science mean to you? Prompt: If you had to describe citizen science to someone else, what would you tell them?

4. Thinking back to before you joined WATER club, describe how aware you were of any water quality issues in Deckers Creek. Did you ever think about the health of Deckers Creek prior to joining the Club? If so, what did you think about?

1. Has your awareness of the Creek's health changed as a result of being in WATER Club? 
2. What have you learned about water quality issues in Deckers Creek because of your involvement in the club?

5. Thinking back to when you first joined this Club, on a scale of 1-10, how confident were you in your ability to do science? Tell me why you chose that rating?

1. Now, after participating in the Club, again on a scale of 1-10, how confident are you in your ability to do science? Tell me why you chose that rating?

2. Prompt-Did participating in the Club impact your confidence about doing science?

6. How did you feel in general about doing science before you joined WATER club? Prompts: Did you enjoy science? Like science? Hate Science? etc.

1. How do you feel now that you've been in the club? Has participating in the Club impacted your feelings about science?

7. Before you joined WATER club, did you think of yourself as someone who was "good" at doing science?

a. Have those feelings changed from being in the club? Has participating changed the way you feel about studying science?

2. Do you think you have contributed to science? Prompts: Why or why not? And how, or in what way?

8. What do you think you've learned about doing science or conducting research from participating in WATER Club?

1. What are some important things to think about when setting up a scientific research project?

2. What water quality parameters did we study in the club? And why did we study those? Can you walk me through how we collected the data?

3. How might the data you collected be used? How is the scientific information you collected helpful to science, or other people and groups?

9. Have you done anything different to help Deckers Creek outside of the Club or in your daily life because of your involvement in the WATER Club? Tell me about that.

10. Do you plan on taking any action in the future to help Deckers Creek?

1. Prompts: Tell me more about those actions. What are one or two things that you could do to help the water quality of Deckers Creek? How would they help the Creek specifically?

11. What parts of WATER club were most important to you? Why?

1. What parts of the project were least important to you? Why?

12. What would you say is your greatest takeaway from participating in the WATER Club?

13. Is there anything else you would like us to know about your experience in WATER club?

1. Any other final thoughts or questions for me?

Wrap up:

"I really appreciate you taking the time to talk with me today. Thank you again for help." 


\section{Appendix B: Question Matrix}

Table 2

Interview questions with related construct, purpose and reference

\begin{tabular}{|c|c|c|}
\hline Question & Construct & Reference \\
\hline $\begin{array}{l}\text { First, let's talk about your } \\
\text { involvement in WATER } \\
\text { Club... } \\
\text { How long have you been a } \\
\text { member of the club? } \\
\text { How often do you come to } \\
\text { WATER Club meetings? } \\
\text { What do you feel your role is } \\
\text { in WATER club? }\end{array}$ & Participation & $\begin{array}{l}\text { Price \& Lee, 2013; Ballard, } \\
\text { Dixon, Harris, } 2017\end{array}$ \\
\hline $\begin{array}{l}\text { Why did you initially join the } \\
\text { club? } \\
\text { Why did you continue to } \\
\text { participate or not? }\end{array}$ & Motivation & \\
\hline $\begin{array}{l}\text { Describe for me what you did } \\
\text { in WATER club? } \\
\text { Tell me about some of the } \\
\text { activities you did in WATER } \\
\text { Club? } \\
\text { Did you participate in any } \\
\text { field trips? } \\
\text { Did you get a chance to talk } \\
\text { about or present your work or } \\
\text { ideas to anyone outside the } \\
\text { Club? What was that like? } \\
\text { What does citizen science } \\
\text { mean to you? Prompt: If you } \\
\text { had to describe citizen science }\end{array}$ & Participation & Knapp \& Poff, 2001 \\
\hline
\end{tabular}




\begin{tabular}{|c|c|c|}
\hline $\begin{array}{l}\text { to someone else, what would } \\
\text { you tell them? }\end{array}$ & & \\
\hline $\begin{array}{l}\text { Thinking back to before you } \\
\text { joined WATER club, describe } \\
\text { how aware you were of any } \\
\text { water quality issues in } \\
\text { Deckers Creek. } \\
\text { Did you ever think about the } \\
\text { health of Deckers Creek prior } \\
\text { to joining the Club? If so, } \\
\text { what did you think about? } \\
\text { Has your awareness of the } \\
\text { Creek's health changed as a } \\
\text { result of being in WATER } \\
\text { Club? } \\
\text { What have you learned about } \\
\text { water quality issues in } \\
\text { Deckers Creek because of } \\
\text { your involvement in the club? }\end{array}$ & Knowledge \& Awareness & \\
\hline $\begin{array}{l}\text { Thinking back to when you } \\
\text { first joined this Club, on a } \\
\text { scale of 1-10, how confident } \\
\text { were you in your ability to do } \\
\text { science? Tell me why you } \\
\text { chose that rating? } \\
\text { Now, after participating in the } \\
\text { Club, again on a scale of } 1-10 \text {, } \\
\text { how confident are you in your } \\
\text { ability to do science? Tell me } \\
\text { why you chose that rating? } \\
\text { Prompt-Did participating in } \\
\text { the Club impact your } \\
\text { confidence about doing } \\
\text { science? }\end{array}$ & Science Self-efficacy & \\
\hline $\begin{array}{l}\text { How did you feel in general } \\
\text { about doing science before }\end{array}$ & Science Self Efficacy & Hiller 2012 \\
\hline
\end{tabular}




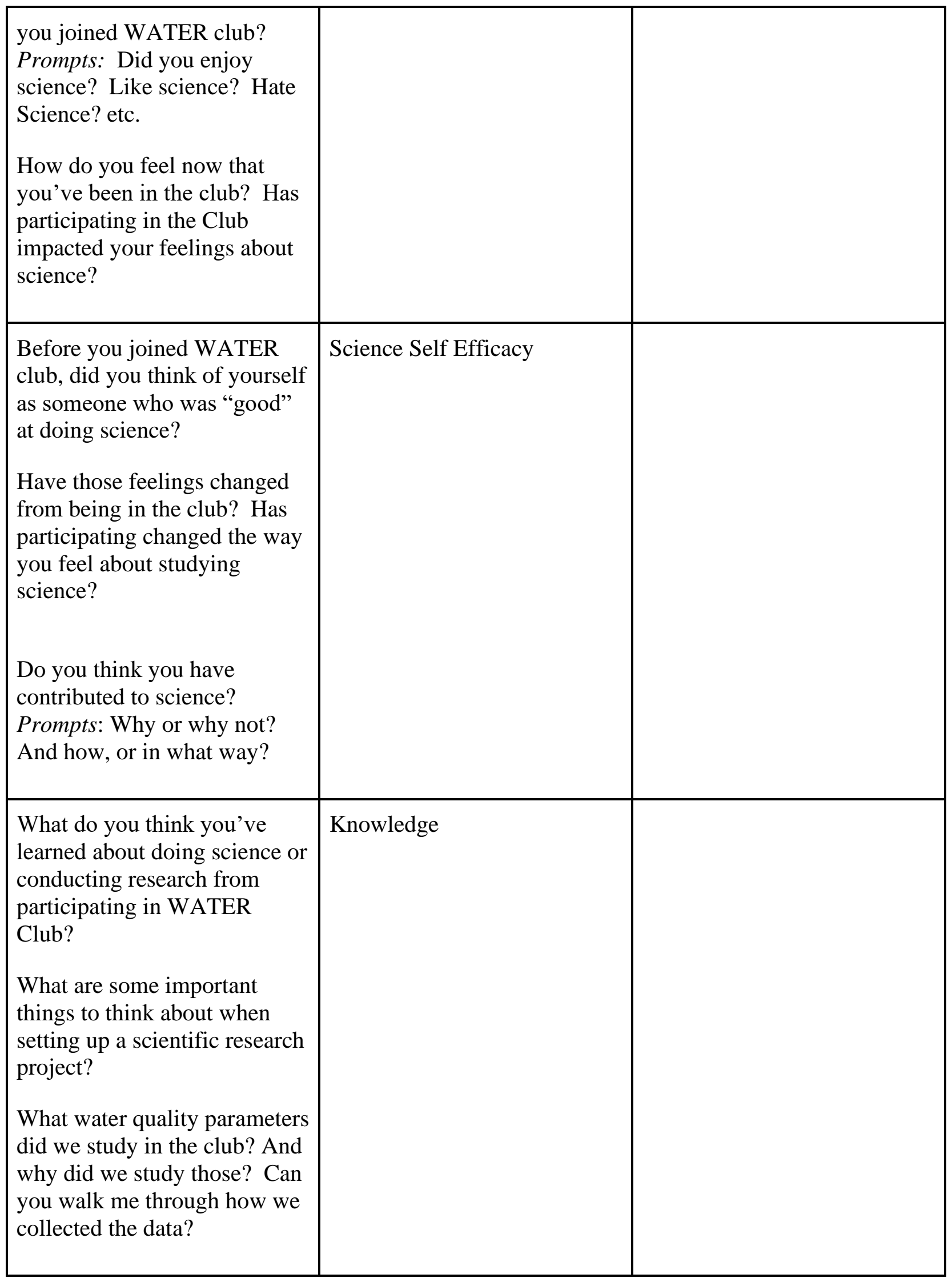




\begin{tabular}{|c|c|c|}
\hline $\begin{array}{l}\text { How might the data you } \\
\text { collected be used? How is the } \\
\text { scientific information you } \\
\text { collected helpful to science, or } \\
\text { other people and groups? }\end{array}$ & & \\
\hline $\begin{array}{l}\text { Have you done anything } \\
\text { different to help Deckers } \\
\text { Creek outside of the Club or } \\
\text { in your daily life because of } \\
\text { your involvement in the } \\
\text { WATER Club? Tell me about } \\
\text { that. }\end{array}$ & Behavior & Tommey \& Domroese 2013 \\
\hline $\begin{array}{l}\text { Do you plan on taking any } \\
\text { action in the future to help } \\
\text { Deckers Creek? } \\
\text { Prompts: Tell me more about } \\
\text { those actions. What are one } \\
\text { or two things that you could } \\
\text { do to help the water quality of } \\
\text { Deckers Creek? How would } \\
\text { they help the Creek } \\
\text { specifically? }\end{array}$ & Behavior & Knapp \& Poff, 2001 \\
\hline $\begin{array}{l}\text { What parts of WATER club } \\
\text { were most important to you? } \\
\text { Why? } \\
\text { What parts of the project were } \\
\text { least important to you? Why? } \\
\text { What would you say is your } \\
\text { greatest takeaway from } \\
\text { participating in the WATER } \\
\text { Club? }\end{array}$ & $\begin{array}{l}\text { Personal relevance to the } \\
\text { program }\end{array}$ & Ballard, Dixon, Harris, 2017 \\
\hline
\end{tabular}




\section{Appendix C: Curriculum \& Activities}

Lesson 1: Stream ID*

Authors: Jessica Kaplan \& Megan Kruger

Overview:

At the end of this activity, $75 \%$ of students will be able to recall at least 4 physical stream health indicators and will be more aware that there are a variety of potential solutions that could be implemented to address stream health problems (chemical and physical). Students will also observe and measure stream health using a stream corridor physical assessment. Students will successfully measure and record water quality parameters using a multimeter probe.

Lesson 2: Watershed Discovery*

Authors: Jessica Kaplan \& Megan Kruger

Overview:

Students will brainstorm and discuss impacts to Deckers Creek through group discussion and guidance from instructors. Students will determine which water quality parameters should be measured to assess the impacts of the various sources of pollution. Then, students will use LaMotte water quality test kits to test for various parameters not collected by citizen science data and discuss their findings.

Lesson 3: Aquatic Macroinvertebrates at Tibbs Run Preserve*

Author: Megan Kruger \& Jessica Kaplan

Overview:

Students will learn about biological indicators of stream health through a benthic macroinvertebrate survey. They will learn the life history of freshwater macro-invertebrates, how aspects of stream health influence them, and how to collect data on them using the West Virginia Department of Environmental Protection sampling methods.

Lesson 4: Data and Analysis*

Author: Jessica Kaplan

Overview:

Students will review the physical, chemical and biological data collected throughout the year and describe how they can best analyze that data based what information is needed to know how to restore portions of Deckers Creek. Students will then receive a tutorial on excel and google sheets and learn how to manipulate their data to create visuals. They will then discuss their findings with their classmates.

Lesson 5: Communication* 
Author: Jessica Kaplan, Dr. Dave Smaldone

Overview: This lesson is comprised of a presentation from Dr. Dave Smaldone, (Principle Investigator of the larger study), on effective communication techniques and an independent club project. Students will create their own communication project using the guidelines from Dr. Smaldone which could include a poster, flyer, news article, etc. Students will then use club meeting time to discuss and workshop their ideas and then will finally present their products at the restoration event to Morgantown community.

See Dr. Dave Smaldone's PowerPoint presentation on effective communication. (available upon request)

\section{Lesson 6: Restoration*}

Author: Jessica Kaplan, Dr. Jim Anderson

Overview: This lesson is comprised of a PowerPoint presentation from Dr. Jim Anderson, Wetland scientist at WVU and a hands-on restoration project planned by students and research staff. Students will learn about stream restoration efforts in Deckers Creek and potential solutions to stream bank erosion from Dr. Jim Anderson. They will then participate in planning meetings with the research staff to develop a stream restoration project. They will then participate in a restoration event focused on restoring the stream bank erosion of Deckers Creek.

See Dr. Jim Anderson’s PowerPoint on stream restoration (available upon request).

*Contact author for full version of lesson plan. 


\section{Appendix D: Student Created Work}

Figure 1. Action Item List

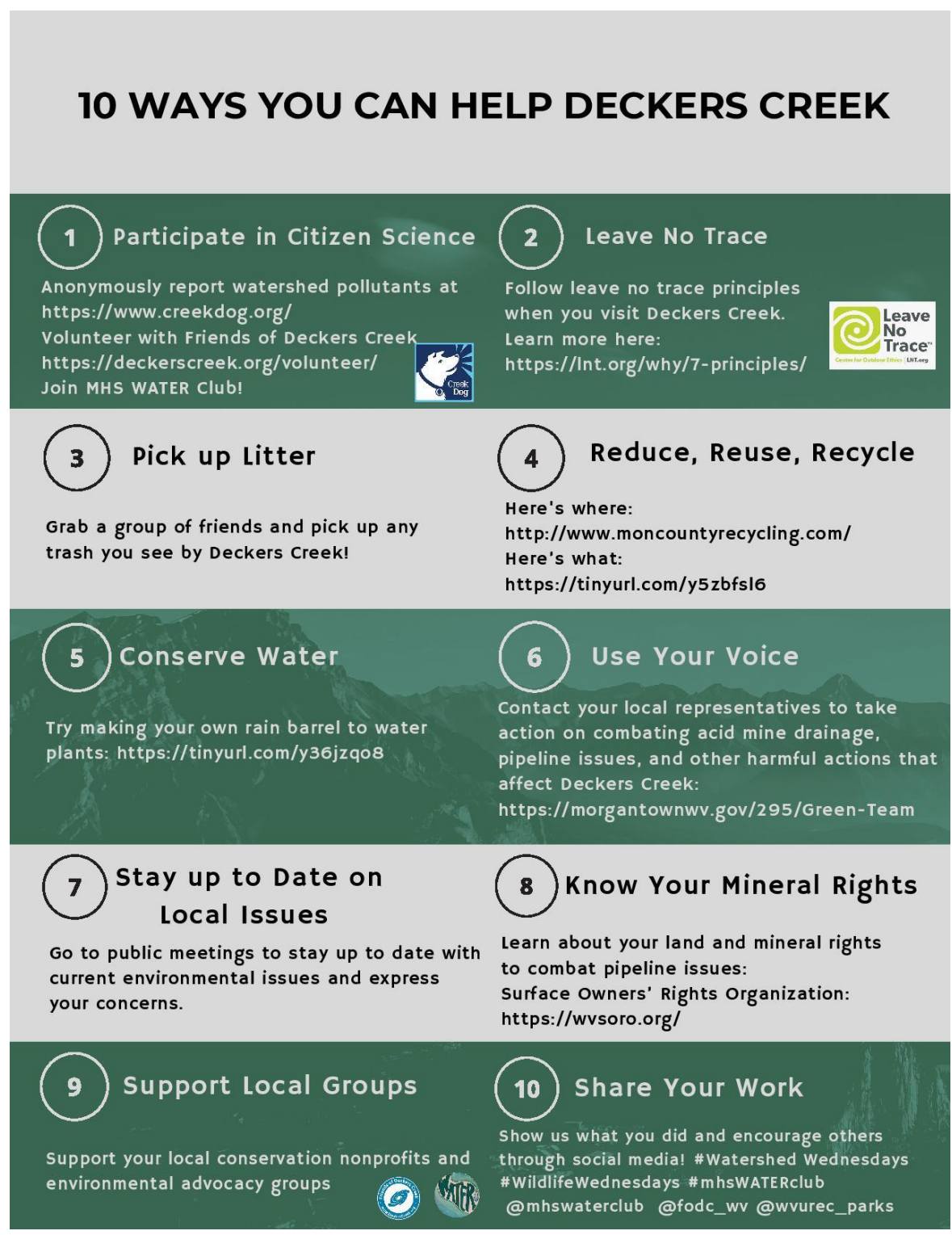

Action Item List. This flyer was distributed at the restoration event in October 2020 and is one of the products from Lesson 5 (Appendix C). 
Figure 2. WATER Club Restoration Poster

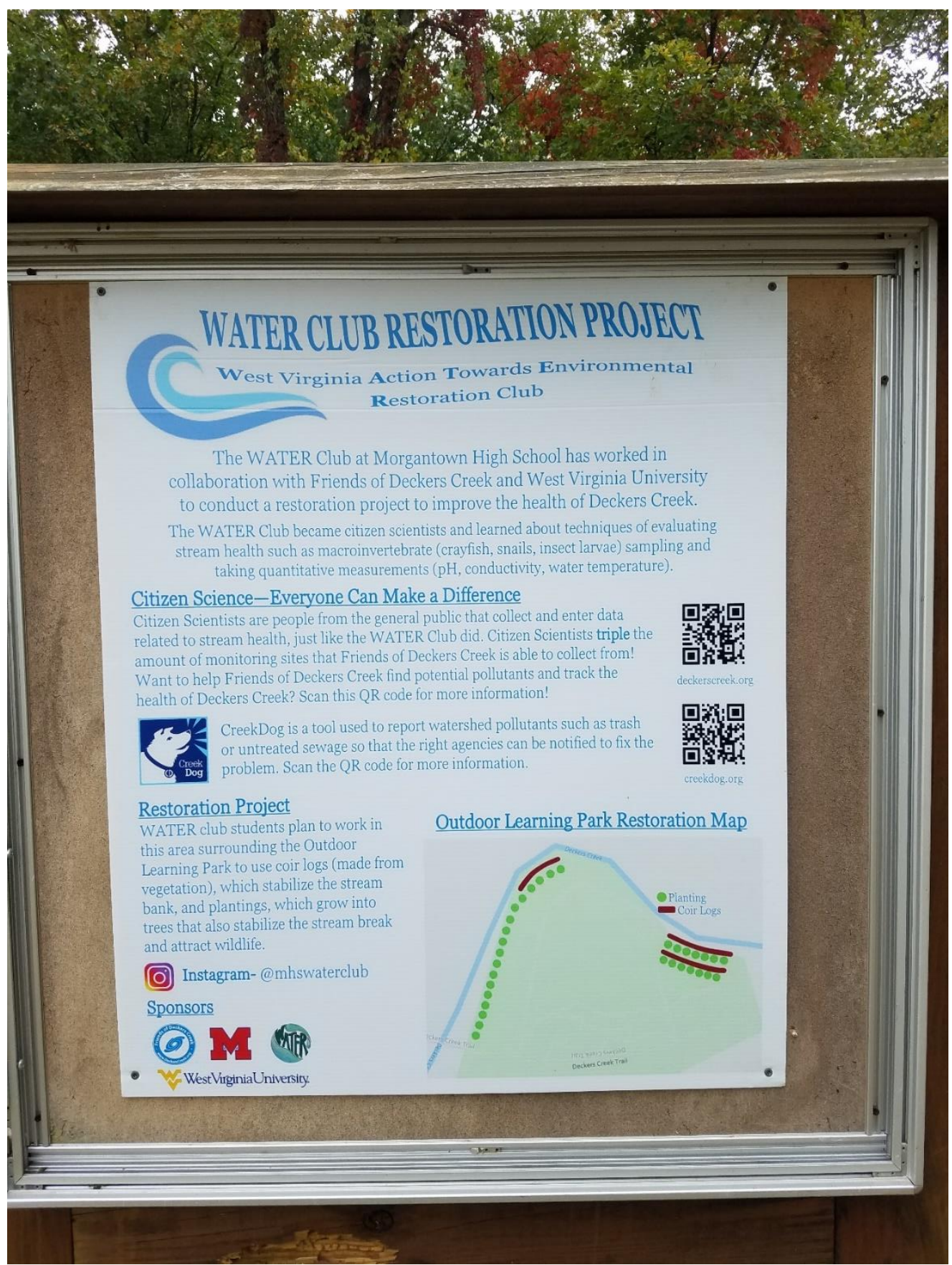

WATER Club Restoration Poster. This poster was designed by students in WATER club and presented at the restoration event in October 2020. It was a product of Lesson 5 (Appendix C). 